\title{
Is the Antidepressant Activity of Selective Serotonin Reuptake Inhibitors Mediated by Nicotinic Acetylcholine Receptors?
}

\author{
Hugo R. Arias ${ }^{1, *, \dagger}$, Katarzyna M. Targowska-Duda ${ }^{2, \dagger}{ }^{\dagger}$ Jesús García-Colunga ${ }^{3,+}{ }^{(1)}$ and Marcelo O. Ortells ${ }^{4}$ \\ 1 Department of Pharmacology and Physiology, Oklahoma State University College of Osteopathic Medicine, \\ Tahlequah, OK 74464, USA \\ 2 Department of Biopharmacy, Medical University of Lublin, 20-093 Lublin, Poland; katarzyna.duda@umlub.pl \\ 3 Departamento de Neurobiología Celular y Molecular, Instituto de Neurobiología, Campus Juriquilla, \\ Universidad Nacional Autónoma de México, Querétaro 76230, Mexico; garciacolunga@unam.mx \\ 4 Facultad de Medicina, Universidad de Morón, CONICET, Morón 1708, Argentina; mortells@retina.ar \\ * Correspondence: hugo.arias@okstate.edu; Tel.: +1-918-525-6324; Fax: +1-918-280-2515 \\ + These authors contributed equally to this work.
}

check for

updates

Citation: Arias, H.R.;

Targowska-Duda, K.M.;

García-Colunga, J.; Ortells, M.O. Is

the Antidepressant Activity of

Selective Serotonin Reuptake

Inhibitors Mediated by Nicotinic

Acetylcholine Receptors? Molecules

2021, 26, 2149. https://doi.org/

$10.3390 /$ molecules 26082149

Academic Editor: Dina Manetti

Received: 12 March 2021

Accepted: 5 April 2021

Published: 8 April 2021

Publisher's Note: MDPI stays neutral with regard to jurisdictional claims in published maps and institutional affiliations.

Copyright: (c) 2021 by the authors. Licensee MDPI, Basel, Switzerland. This article is an open access article distributed under the terms and conditions of the Creative Commons Attribution (CC BY) license (https:/ / creativecommons.org/licenses/by/ $4.0 /)$.

\begin{abstract}
It is generally assumed that selective serotonin reuptake inhibitors (SSRIs) induce antidepressant activity by inhibiting serotonin (5-HT) reuptake transporters, thus elevating synaptic 5-HT levels and, finally, ameliorates depression symptoms. New evidence indicates that SSRIs may also modulate other neurotransmitter systems by inhibiting neuronal nicotinic acetylcholine receptors (nAChRs), which are recognized as important in mood regulation. There is a clear and strong association between major depression and smoking, where depressed patients smoke twice as much as the normal population. However, SSRIs are not efficient for smoking cessation therapy. In patients with major depressive disorder, there is a lower availability of functional nAChRs, although their amount is not altered, which is possibly caused by higher endogenous ACh levels, which consequently induce $\mathrm{nAChR}$ desensitization. Other neurotransmitter systems have also emerged as possible targets for SSRIs. Studies on dorsal raphe nucleus serotoninergic neurons support the concept that SSRI-induced nAChR inhibition decreases the glutamatergic hyperstimulation observed in stress conditions, which compensates the excessive 5-HT overflow in these neurons and, consequently, ameliorates depression symptoms. At the molecular level, SSRIs inhibit different nAChR subtypes by noncompetitive mechanisms, including ion channel blockade and induction of receptor desensitization, whereas $\alpha 9 \alpha 10$ nAChRs, which are peripherally expressed and not directly involved in depression, are inhibited by competitive mechanisms. According to the functional and structural results, SSRIs bind within the nAChR ion channel at high-affinity sites that are spread out between serine and valine rings. In conclusion, SSRI-induced inhibition of a variety of nAChRs expressed in different neurotransmitter systems widens the complexity by which these antidepressants may act clinically.
\end{abstract}

Keywords: selective serotonin reuptake inhibitors; antidepressants; nicotinic acetylcholine receptors; noncompetitive antagonists; neuronal pathways; molecular modeling

\section{Introduction}

Major depressive disorder (MDD), also known as clinical depression, is a neuropsychiatric disorder characterized by depressed mood, sleep and cognitive disturbances, anxiety, anhedonia or decreased interest in enjoyable activities, and suicidal thoughts, among other symptoms [1]. Although the etiology of MDD and related depression disorders is not fully understood, it is very complex and depends on neuronal, genetic, biological, cognitive, sociocultural, and psychological aspects [2-4].

Previous studies have determined that the malfunctioning of certain brain regions could be one important aspect in the development of MDD [5]. The most important brain abnormalities associated with depression are located in the prefrontal neocortex, limbic 
system, basal ganglia, and brain stem regions. In animal models of depression, as well as in depressed patients, the size and number of synapses are significantly reduced in several brain areas, including the nucleus accumbens (NAc), amygdala, cingulate cortex, hippocampus, and prefrontal cortex (PFC) [2-4].

Several hypotheses have been described and proposed in order to elucidate the etiology of MDD, but each one includes various neurotransmitter systems [6,7]. One of the first and most extensive depression hypotheses is associated with the decrease in extracellular neurotransmitter levels, such as serotonin (5-HT), dopamine (DA), and noradrenaline (NA) [8]. In this regard, substances that might elevate monoamine levels would be beneficial for depression treatment. Since the 1950s, MDD patients have been treated with monoamine oxidase inhibitors, which block monoamine reuptake and/or metabolism (e.g., selegiline) $[9,10]$. Among monoamine reuptake inhibitors, selective serotonin reuptake inhibitors (SSRIs; molecular structures are presented in Figure 1) have been classified as some of the most effective substances [7].<smiles>CNCCC(Oc1ccc(C(F)(F)F)cc1)c1ccccc1</smiles>

Fluoxetine

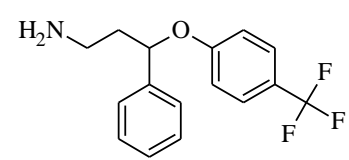

Nor-fluoxetine<smiles>CN[C@H]1CCC(c2ccc(Cl)c(Cl)c2)c2ccccc21</smiles>

Sertraline<smiles>Fc1ccc(C2CCNCC2COc2ccc3c(c2)OCO3)cc1</smiles>

Paroxetine

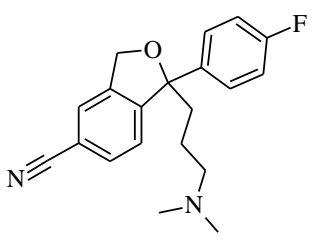

Citalopram

Figure 1. Molecular structures of clinically used selective serotonin reuptake inhibitors (SSRIs) that also inhibit various nicotinic acetylcholine receptor (nAChR) subtypes.

The cholinergic-adrenergic hypothesis proposes that the underlying cause of depression is an imbalance between the content of acetylcholine (ACh) and NA, producing an overstimulation of the cholinergic system over the noradrenergic system [11]. Cholinergic neurotransmission, which is mediated by muscarinic and nicotinic receptors, has been related to various neurophysiological processes, such as attention, learning and memory, mood, and appetite changes, as well as pathological conditions, including anxiety disorders and MDD [12-14]. Higher than normal extracellular levels of ACh and its hydrolysis metabolite, choline, have been observed in patients with depression [14-16]. Moreover, treatment with physostigmine, an acetylcholinesterase (AChE) inhibitor that increases the levels of synaptic ACh, elicited depression symptoms in humans [17-19] and depression-like effects in rodents [20].

Mounting evidence supports the view that other neurotransmitter circuits and pathways are involved in the clinical activity of SSRIs, including those modulated by nicotinic ACh receptors (nAChRs). This review focuses on functional, preclinical, therapeutic, and structural studies that support the activity of SSRIs on different nAChR subtypes.

\section{Selective Serotonin Reuptake Inhibitors (SSRIs)}

To date, the most accepted and best characterized mechanism of action for SSRIs is centered on the inhibition of serotonin transporters (SERT) located at presynaptic terminals. The first action of SSRIs is to inhibit SERT, increasing the synaptic levels of 5-HT up to seven-fold [21-23]. This elevated 5-HT concentration, in turn, activates a variety of postsynaptic 5-HT receptors in several brain areas, with result in changes in serotoninergic 
signaling, which is believed to attenuate depression conditions [24,25]. Furthermore, high extracellular concentrations of 5-HT trigger a negative feedback mechanism involving $5-\mathrm{HT}_{1 \mathrm{~A}}$ autoreceptors, which regulate 5-HT levels in the synaptic cleft. A high endogenous concentration of 5-HT may be sufficient for inhibiting nAChRs [26,27].

SSRIs are extensively used medications for the treatment of MDD and other neuropsychiatric maladies, including obsessive-compulsive disorders, panic disorders, alcoholism, obesity, migraines, and chronic pain [25,28,29]. For example, sertraline and paroxetine are prescribed for the treatment of panic attacks, obsessive-compulsive disorders, posttraumatic stress disorders, social anxiety disorders, and premenstrual dysphoric disorders, a severe form of premenstrual syndrome (https:/ / www.webmd.com/ corporate/default. $\mathrm{htm}$ ). Fluoxetine is also employed in the treatment of eating disorders and slow-channel congenital myasthenic syndromes $[29,30]$. A common feature in both conditions is that of higher ACh concentrations compared to those in the normal population [20,30,31]. In slowchannel congenital myasthenic syndromes, high levels of ACh open slow-channel mutant $\mathrm{nAChRs}$ with long-lasting durations, allowing more cation influx into the endplate after an early onset of progressive muscle weakness [30,32]. Therefore, fluoxetine restores the pathological condition of congenital myasthenic syndromes by decreasing both the channel opening frequency and channel open time, as well as increasing the channel closed time.

Although SSRIs are used in many clinical conditions, the exact mechanisms underlying their clinical effects are not very clear. A plausible mechanism is that SSRIs, in addition to inhibiting SERT (e.g., fluoxetine inhibitory potency $\left(\mathrm{IC}_{50}\right)=6-17 \mathrm{nM}$ [33-35]), modulate other targets, including a variety of nAChRs.

\section{Nicotinic Acetylcholine Receptor Functions Modulate Depression States}

nAChRs are members of the pentameric ligand-gated ion channel superfamily that also comprises 5-HT type 3, glycine, and $\gamma$-aminobutyric acid type A receptors. nAChRs are involved in a variety of physiological and pathological processes in both neuronal and non-neuronal tissues. In general, presynaptic nAChRs modulate the release of a variety of neurotransmitters, including those implicated in depression [36,37], whereas postsynaptic $n A C h R s$ mediate stimulatory transmission across the central and peripheral nervous systems $[38,39]$.

The malfunctioning of nAChRs (by excessive or decreased activity) expressed in circuits regulating mood has been implicated in the development of anxiety states and MDD $[15,40,41]$. As part of the same concept, an imbalance between the cholinergic and noradrenergic systems - the so-called "cholinergic-adrenergic hypothesis of depression" where the former system is more sensitive or more stimulated than the latter might cause MDD to develop [11]. In this regard, $\mathrm{nAChR}$ inhibition exerted by structurally different antidepressants, including SSRIs, could be relevant for their clinical efficacy [15].

The involvement of nAChRs in MDD has also been supported by studies using different brain imaging techniques. For instance, single-photon-emission computed tomography studies showed that the densities of $\beta 2^{*} \mathrm{nAChRs}\left({ }^{*}\right.$ indicates that other different subunits are potentially present) in the brains of patients with MDD and of healthy subjects were similar [42]. These results indicate that the number of nAChRs is not an important factor in the development of MDD. Nevertheless, a lower availability of $\beta 2^{*} \mathrm{nAChRs}$ was determined in the cortex, thalamus, cerebellum, striatum, hippocampus, amygdala, and brainstem in patients with either depression [42] or bipolar depression [43] compared to healthy subjects. This lower receptor availability could be caused by higher levels of endogenous Ach, which may result in receptor desensitization [42], a closed state that is unresponsive to $\mathrm{ACh}$ or other agonists. Moreover, positron emission tomography studies showed that Parkinson's patients with depression symptoms had decreased levels of $\alpha 4 \beta 2^{*}$ $n A C h R s$ within subcortical regions, such as the putamen (involved in reward) and midbrain (where hypoactivity of 5-HT, DA, and/or NA has been related to MDD), as well as in cortical regions, including the anterior cingulate cortex and occipital cortex [44]. These 
data support the notion that altered nAChR-induced neurotransmission plays a role in the development of MDD.

\section{Relationship between Smoking and Depression}

Preclinical and clinical studies support the involvement of nAChRs in MDD [15,20,45,46]. Although the causality between nicotine exposure and depression remains unclear, clinical evidence supports a bidirectional association and dose-dependent relationship between smoking and depression [47]. For example, depressed patients smoke twice as much as the average population, probably to control their mood symptoms. People smoking more than twenty cigarettes per day double their risk of subsequent depression during their lives. Paradoxically, however, the chronic use of nicotine may lead to the development of depression symptoms, probably through a process involving nicotine-induced receptor desensitization $[14,40,48,49]$. This evidence highlights the correlation between smoking habits and increased risks of depression disorders, which, in turn, will increase the chances of using antidepressants in the long term.

A proposed mechanism by which smoking induces depression is that the excess of nicotine activates nAChRs and, consequently, the cholinergic signaling, thus breaking the balance between the cholinergic and noradrenergic systems [14,40,50,51]. Depression states, in turn, may increase the rate of smoking due to mood changes, which are positively correlated with the quantity of tobacco used. Additionally, chronic smoking leads to desensitization and upregulation of high-affinity $\beta 2^{*} \mathrm{nAChRs}$ (i.e., $\alpha 4 \beta 2^{*}, \alpha 6 \beta 2^{*}$ ) (see more details below), which, in turn, could contribute to depression symptoms [31,52]. In this regard, smokers and nonsmokers might respond differently to antidepressants, but the effects of smoking on treatment outcomes have rarely been examined and are therefore unclear. Depression symptoms in adults were more attenuated when an SSRI was combined with mecamylamine, a nonselective $\mathrm{nAChR}$ antagonist with antidepressant-like activity [53], compared to the SSRI alone [54]. Other analyses, however, have shown that smokers respond less to this drug combination than nonsmokers [55].

Additional studies also highlighted the importance of the cholinergic system in the development of depression. For example, augmenting ACh content by decreasing the AChE activity using the inhibitor physostigmine or virally delivered shRNAs produced depression-like behavior in rodents [20]. This is in accordance with the hypothesis that subjects with depression have higher endogenous ACh content, which may overstimulate the cholinergic system [42]. On the other hand, structurally different $\mathrm{nAChR}$ antagonists also produce antidepressant-like effects, probably by limiting nAChR function $[14,45,46]$.

Anhedonia, a main symptom in major depression, has been linked to dysfunctions in the brain reward system, particularly when the DA content is decreased [56]. Therefore, a biochemical hypothesis of nicotine dependence [57] could also explain its relationship with nicotine-modulating neuronal pathways and depression. The initial and intrinsic biochemical basis of tobacco addiction should be found in the mechanisms by which nicotine promotes different effects on $\mathrm{nAChRs}$. According to this model, nAChR desensitization and upregulation, but not activation, are compatible molecular processes that effectively cause nicotine dependence [58]. In addition to the classical desensitization process, low agonist concentrations can induce desensitization even without $\mathrm{nAChR}$ activation, a process called "high-affinity desensitization" [59]. This is a slow process that, in the prolonged presence of low concentrations of nicotine $(\sim 0.5 \mu \mathrm{M})$, preferentially affects $\alpha 4 \beta 2^{*}$ compared to $\alpha 7^{*}$ nAChRs. Nicotine accumulation during a smoking day is enough to produce nAChR desensitization. At nicotine concentrations present in chronic smokers' brains, $\alpha 4 \beta 2^{*} \mathrm{nAChRs}$ are preferably desensitized and subsequently upregulated in contrast to $\alpha 7^{*} \mathrm{nAChRs}$. Since presynaptic $\alpha 4 \beta 2^{*}$ nAChRs regulate GABA release onto dopaminergic neurons, a possibility is that nicotine-induced $\mathrm{nAChR}$ desensitization decreases GABAergic inhibition of dopaminergic neurons, and the consequent disinhibition finally promotes rewarding effects. After chronic nicotine use, however, the subsequent upregulation of $\alpha 4 \beta 2^{*} \mathrm{nAChRs}$ enhances the inhibitory action of GABA on dopaminergic neurons, and consequently, even 
more nicotine is needed to restore at least a basal level of reward, leading to a vicious circle of nicotine-induced $\alpha 4 \beta 2^{*}$ desensitization (reward) and upregulation (enhanced reward inhibition).

To test this hypothesis, the effect of nicotine at smoking concentrations $(0.3 \mu \mathrm{M})$ on GABAergic transmission was determined in pyramidal neurons from the medial PFC (mPFC), which modulates the brain's reward circuitry [60]. The results clearly indicated that nicotine inhibits GABAergic postsynaptic currents by activating non- $\alpha 7$ - probably $\alpha 4 \beta 2^{*}$ and $\alpha 6 \beta 2^{*}-\mathrm{nAChRs}$, whereas the role of $\alpha 7^{*} \mathrm{nAChRs}$ in this process was less clear. These results contrasted with those of studies in the hippocampus, where $\alpha 7^{*} \mathrm{nAChRs}$ were the main subtype involved in nicotine-induced modulation [61]. Our study also showed that nicotine increased membrane conductance, probably by activating postsynaptic $\alpha 7^{*} \mathrm{nAChRs}$, and decreased current frequency, corroborating the role of presynaptic $\beta 2^{*}$ $n A C h R s$ in GABA release. In other words, our study supported the activation of pre- and post-synaptic $\alpha 7^{*}$ and $\beta 2^{*}$ nAChRs in GABAergic modulation, while the possibility that $\mathrm{nAChR}$ desensitization is also involved in this process could not be ruled out [60].

There is also comorbidity between depression and anxiety conditions and nicotine addiction [41], highlighting the relationship between these psychiatric disorders and nAChR functioning. Although different antidepressants are successfully used in the treatment of both depression and anxiety, only bupropion and nortriptyline produced long-term beneficial effects when used for smoking cessation, whereas fluoxetine was effective only in smokers with strong depressive symptoms [62,63]. Moreover, non-selective antidepressants, such as monoamine oxidase inhibitors, did not produce benefits in smoking cessation therapy [62].

\section{Preclinical Studies with Combinations of SSRIs and Nicotinic Ligands}

There is experimental evidence showing that nicotinic ligands modulate the antidepressant-like activity of SSRIs. For instance, microdialysis analyses evidenced that nicotine elevates 5-HT levels in the frontal cortex during the initial $15 \mathrm{~min}$, while nicotine in the presence of fluoxetine increases and prolongs the release of 5-HT for at least $2 \mathrm{~h}$, and these effects were blocked by pretreatment with mecamylamine [64]. Additional studies determined that nicotine-evoked 5-HT release depends on $\alpha 7 \mathrm{nAChR}$ activation [46]. For instance, the combined administration of the $\alpha 7$-selective agonist PNU-282987 at a dose (30 mg/ kg) that causes full receptor occupancy [65] with a subactive dose of citalopram ( $3 \mathrm{mg} / \mathrm{kg}$ ), which inhibits $\sim 50 \%$ of the SERT but is unable to induce antidepressant-like activity in mice per se $[46,66]$, causes antidepressant-like effects. Since PNU-282987 alone showed no antidepressant-like activity, it is possible that the combination of $\alpha 7 \mathrm{nAChR}$ activation and partial SERT inhibition was responsible for the observed antidepressant-like effects, confirming $\mathrm{nAChRs}$ as targets for the treatment of major depression.

Although the administration of nicotine alone showed no effect in the tail suspension test (i.e., a very useful animal test to determine the antidepressant-like activity of drugs) and citalopram alone produced a slight decrease in immobility, the co-administration of both drugs resulted in a robust antidepressant-like activity [67]. Moreover, mecamylamine, but not dihydro- $\beta$-erythroidine $\left(\mathrm{DH} \beta \mathrm{E}\right.$ ) (antagonist with relative selectivity for $\beta 2^{*} \mathrm{nAChRs}$, including $\alpha 4 \beta 2^{*}$ and $\alpha 6 \beta 2^{*}$ ), increased the antidepressant-like effect of citalopram [67], suggesting that these $\mathrm{nAChR}$ subtypes are not involved in the antidepressant activity of SSRIs. The latter coincides with $\mathrm{Ca} 2+$ influx experiments where citalopram had the lowest inhibitory potency for $\alpha 4 \beta 2$ nAChRs compared to other SSRIs [68] (Table 1). These results contrasted with the evidence that both mecamylamine and DH $\beta E$ enhanced the antidepressant-like activity of imipramine (a tricyclic antidepressant that blocks both NE and DA reuptake transporters), suggesting that both functionally different antidepressants target distinct $\mathrm{nAChR}$ subtypes. 
Table 1. Inhibitory potency (IC50) of SSRIs for different nAChR subtypes.

\begin{tabular}{|c|c|c|c|c|}
\hline $\begin{array}{l}\text { nAChR } \\
\text { Subtype }\end{array}$ & SSRI & Method & $\mathrm{IC}_{50}(\mu \mathrm{M})$ & References \\
\hline \multirow{4}{*}{$\mathrm{h} \alpha 4 \beta 2$} & \multirow{2}{*}{ Fluoxetine } & Voltage-clamp & 1.83 & [69] \\
\hline & & $\mathrm{Ca}^{2+}$ influx & $4.4 \pm 0.6$ & [70] \\
\hline & Paroxetine & $\mathrm{Ca}^{2+}$ influx & $8.6 \pm 2.3$ & {$[70]$} \\
\hline & Citalopram & $\mathrm{Ca}^{2+}$ influx & $19.0 \pm 4.2$ & [68] \\
\hline \multirow{4}{*}{$\mathrm{r} \alpha 2 \beta 4$} & \multirow{2}{*}{ Fluoxetine } & \multirow{2}{*}{ Voltage-clamp } & $0.37^{\mathrm{b}}$ & [71] \\
\hline & & & $0.45 \pm 0.03^{c}$ & [27] \\
\hline & Nor-fluoxetine & Voltage-clamp & $0.13^{b}$ & [71] \\
\hline & Zimelidine & Voltage-clamp & $0.67^{b}$ & [71] \\
\hline \multirow{3}{*}{$\mathrm{h} \alpha 3 \beta 4$} & Fluoxetine & $\mathrm{Ca}^{2+}$ influx & $2.0 \pm 0.4$ & [70] \\
\hline & Paroxetine & $\mathrm{Ca}^{2+}$ influx & $2.6 \pm 0.3$ & [70] \\
\hline & Citalopram & $\mathrm{Ca}^{2+}$ influx & $5.1 \pm 1.3$ & {$[68]$} \\
\hline $\mathrm{r} \alpha 3 \beta 4$ & Fluoxetine & Voltage-clamp & $0.64 \pm 0.03^{c}$ & [27] \\
\hline & & Voltage-clamp & $0.3 \pm 0.045^{\mathrm{d}}$ & \\
\hline $\mathrm{r} \alpha 4 \beta 4$ & Fluoxetine & $\left(+100-200 \mu \mathrm{M} \mathrm{Zn}^{2+}\right)$ & $0.17 \pm 0.018^{d}$ & {$[7 / 2]$} \\
\hline \multirow{3}{*}{$\mathrm{r} \alpha 3 \beta 4 \alpha 5$} & Fluoxetine & ${ }^{86} \mathrm{Rb}^{+}$efflux & 2.5 & [73] \\
\hline & Paroxetine & ${ }^{86} \mathrm{Rb}^{+}$efflux & 4.9 & [73] \\
\hline & Sertraline & ${ }^{86} \mathrm{Rb}^{+}$efflux & 3.1 & [73] \\
\hline \multirow{8}{*}{$\mathrm{h} \alpha 7$} & \multirow{4}{*}{ Fluoxetine } & Voltage-clamp & 1.6 & [74] \\
\hline & & $\mathrm{Ca}^{2+}$ influx & $4.7 \pm 0.83$ & [75] \\
\hline & & $\mathrm{Ca}^{2+}$ influx & $4.9 \pm 1.0$ & [70] \\
\hline & & Voltage-clamp & 5.27 & [69] \\
\hline & \multirow{2}{*}{ Paroxetine } & $\mathrm{Ca}^{2+}$ influx & $8.6 \pm 2.0$ & [70] \\
\hline & & $\mathrm{Ca}^{2+}$ influx & $9.1 \pm 0.6$ & [75] \\
\hline & Sertraline & $\mathrm{Ca}^{2+}$ influx & $10.0 \pm 0.81$ & [75] \\
\hline & Citalopram & $\mathrm{Ca}^{2+}$ influx & $18.8 \pm 1.1$ & [68] \\
\hline \multirow{3}{*}{$\begin{array}{l}\text { Hippocampal } \\
\operatorname{r} \alpha 7^{*}\end{array}$} & Nor-fluoxetine & Voltage-clamp & $0.82 \pm 0.04^{\mathrm{a}}$ & [76] \\
\hline & Fluoxetine & Voltage-clamp & $0.66 \pm 0.06^{\mathrm{a}}$ & [76] \\
\hline & Escitalopram & Voltage-clamp & $28.9 \pm 5.1$ & [76] \\
\hline$h \alpha 3 \beta 2$ & Fluoxetine & Voltage-clamp & 4.14 & [69] \\
\hline $\mathrm{r} \alpha 9 \alpha 10$ & Citalopram & Voltage-clamp & $7.5 \pm 0.9$ & {$[68]$} \\
\hline \multirow{6}{*}{$\operatorname{m} \alpha 1 \beta 1 \gamma \delta$} & \multirow{6}{*}{ Fluoxetine } & ${ }^{86} \mathrm{Rb}^{+}$efflux & 2.1 & [73] \\
\hline & & Voltage-clamp $(0 \mathrm{mV})$ & 2.2 & [26] \\
\hline & & Voltage-clamp & $0.45 \pm 0.04^{\mathrm{d}}$ & \\
\hline & & $\left(+100-200 \mu \mathrm{M} \mathrm{Zn}{ }^{2+}\right)$ & $0.19 \pm 0.02^{d}$ & [72] \\
\hline & & Voltage-clamp & $0.22^{b}$ & [71] \\
\hline & & Voltage-clamp & $0.3^{\mathrm{e}}$ & [27] \\
\hline \multirow{4}{*}{$h \alpha 1 \beta 1 \gamma \delta$} & \multirow{4}{*}{ Fluoxetine } & $\mathrm{Ca}^{2+}$ influx: & & \\
\hline & & 5 min pre-incubation & $1.8 \pm 0.6$ & \\
\hline & & 240 min pre-incubation & $0.22 \pm 0.01$ & [77] \\
\hline & & 1440 min pre-incubation & $0.17 \pm 0.08$ & \\
\hline \multirow[b]{2}{*}{$h \alpha 1 \beta 1 \varepsilon \delta$} & \multirow{2}{*}{ Fluoxetine } & \multirow{2}{*}{$\mathrm{Ca}^{2+}$ influx } & $0.85^{\mathrm{b}}$ & \\
\hline & & & $0.55^{b}$ & [30] \\
\hline$m \alpha 1 \beta 1 \gamma \delta$ & Nor-fluoxetine & Voltage-clamp & $0.07^{b}$ & [71] \\
\hline $\mathrm{h} \alpha 1 \beta 1 \gamma \delta$ & Paroxetine & $\begin{array}{l}\mathrm{Ca}^{2+} \text { influx: } 5 \mathrm{~min} \\
\text { pre-incubation }\end{array}$ & $4.8 \pm 0.6$ & [77] \\
\hline
\end{tabular}


Table 1. Cont.

\begin{tabular}{|c|c|c|c|c|}
\hline $\begin{array}{l}\text { nAChR } \\
\text { Subtype }\end{array}$ & SSRI & Method & $\mathrm{IC}_{50}(\mu \mathrm{M})$ & References \\
\hline \multirow{2}{*}{$m \alpha 1 \beta 1 \gamma \delta$} & Paroxetine & ${ }^{86} \mathrm{Rb}^{+}$efflux & 5.6 & [73] \\
\hline & Sertraline & ${ }^{86} \mathrm{Rb}^{+}$efflux & 3.5 & [73] \\
\hline $\begin{array}{l}\text { Habenular } \\
\mathrm{m} \alpha 3 \beta 4^{*}\end{array}$ & Citalopram & Patch-clamp & $7.6 \pm 1.0$ & [68] \\
\hline \multirow{2}{*}{$\begin{array}{l}\text { Hippocampal } \\
\text { nAChRs }\end{array}$} & Citalopram & $\begin{array}{l}\text { Nicotine-evoked } \\
\text { NA release }\end{array}$ & 0.93 & [78] \\
\hline & Fluoxetine & $\begin{array}{l}\text { Nicotine-evoked } \\
\text { NA release }\end{array}$ & 0.57 & [78] \\
\hline $\begin{array}{l}\text { nAChRs from } \\
\text { superior cervical } \\
\text { ganglion }\end{array}$ & Fluoxetine & $\mathrm{Ca}^{2+}$ influx & 2.0 & [69] \\
\hline
\end{tabular}

\section{SSRIs Inhibit nAChRs at Clinical Concentrations}

SSRIs inhibit a variety of $\mathrm{nAChR}$ subtypes with distinct potencies (Table 1) and by different mechanisms $[26,27,30,70,71,74,77]$. This functional inhibition may reduce the exacerbated cholinergic activity observed during depression conditions, which is consistent with the cholinergic hypothesis of depression [11,17-20].

Although $\mathrm{Ca}^{2+}$ influx results established that fluoxetine is the most potent SSRI in inhibiting a variety of nAChR subtypes, the use of different functional assays did not give only one value, but a range of values for each SSRI. Table 1 shows that the activity of each SSRI also depends on the studied nAChR subtype. For example, the potency of both fluoxetine and paroxetine was practically the same in the h $\alpha 3 \beta 4 \mathrm{nAChR}$, while two-fold-lower values were determined for citalopram in the same receptor subtype. Considering a single $\mathrm{nAChR}$ subtype, the calculated $\mathrm{IC}_{50}$ values depended on the type of SSRI molecule. For example, the following inhibitory potency rank order was determined at h $\alpha 4 \beta 2$ nAChRs $\left(\mathrm{IC}_{50}\right.$ 's in $\left.\mu \mathrm{M}\right)$ : fluoxetine $(4.4 \pm 0.6)>$ paroxetine $(8.6 \pm 2.3)>$ citalopram $(19.0 \pm 4.2)$ (Table 1).

Although, in general, SSRIs inhibit nAChRs through noncompetitive mechanisms, the inhibition at the $\alpha 9 \alpha 10 \mathrm{nAChRs}$ is mediated by a competitive mechanism. Voltageclamp results revealed that citalopram inhibits ACh-evoked $\alpha 9 \alpha 10$ currents in a voltageindependent and competitive manner [68]. This inhibitory mechanism was also observed in structurally different antidepressants, such as imipramine [79]. Since $\alpha 9 \alpha 10 \mathrm{nAChRs}$ are not expressed in the brain, but preferably in peripheral immunocompetent cells [80], the inhibitory mechanism observed at this receptor is not relevant for the clinical efficacy of SSRIs in depression, but might be related to their anti-inflammatory activity [81].

An important aspect for determining whether SSRIs inhibit nAChRs at clinically relevant concentrations is the calculation of the plasma/brain ratio after drug treatment. The determined levels of SSRIs in plasma were generally lower than those in the brain. For example, after administration of $40 \mathrm{mg}$ /day fluoxetine for 30 days, the plasma concentration could reach $0.29-0.97 \mu \mathrm{M}$, and in some patients, up to $1.6 \mu \mathrm{M}[82,83]$. A wide range of brain-to-plasma ratios (2.6-20) has been calculated for fluoxetine [84,85], which is concurrent with the relatively higher brain concentration $(13 \mu \mathrm{M})$ [86]. Post-mortem studies in individuals that had been taking citalopram showed brain concentrations of $4.7 \pm 3.3 \mu \mathrm{M}$, which was approximately four-fold higher than that in plasma [87]. Accordingly, it is feasible that different $\mathrm{nAChR}$ subtypes can be inhibited - at least partially - by SSRIs (Table 1). By meticulously determining both the inhibitory activity of SSRIs, such as fluoxetine, sertraline, paroxetine, and citalopram, at $\alpha 4 \beta 2 \mathrm{nAChRs}$ and the free brain level of each SSRI, a functional inhibition of only $\sim 2.5 \%$ was calculated, a percentage that was 
10-fold lower than that estimated to be necessary to produce a noticeable antidepressantlike activity [88]. In comparison, the calculated free mecamylamine concentration in the brain supported $\sim 20 \%$ inhibition of the $\alpha 4 \beta 2^{*} \mathrm{nAChR}$ function [88]. Although these results suggest that $\alpha 4 \beta 2 \mathrm{nAChRs}$ are not important for the antidepressant-like activity of SSRIs, there are other $\mathrm{nAChR}$ candidates that might be involved. For instance, habenular $\alpha 3 \beta 4^{*}$ and hippocampal $\alpha 7^{*}$ nAChRs (Table 1 ), as well as $\alpha 6 \beta 2^{*}$ nAChRs, are expressed in the brain reward system. Although no information on the effect of SSRIs at $\alpha 6 \beta 2^{*}$ $n A C h R s$ is currently available, there is experimental evidence indicating that modulation of $\alpha 6^{*} \mathrm{nAChRs}$ by LF-3-88, a novel partial agonist that would pharmacologically act like a competitive antagonist, induces antidepressant-like effects in several mouse models [89].

\section{Neuronal Pathways Involved in the Antidepressant Activity of SSRIs}

Since activation of presynaptic nAChRs modulates the release of several neurotransmitters involved in mood regulation, the malfunctioning of these receptors expressed in different neuronal pathways might be related to mood disorders $[31,33]$. Considering that SSRIs inhibit different nAChRs (Table 1), the simplest contemplated mechanism by which SSRIs might regulate nicotinic pathways involves the inhibition of presynaptic nAChRs. According to the cholinergic hypothesis of depression, SSRIs might recover the unbalance of cholinergic signaling by direct inhibition of presynaptic nAChRs expressed in brain regions associated with depression $[15,90]$. Nevertheless, new evidence supports the notion that the mechanism of action of SSRIs is more complex than we previously thought, and involves many neurotransmitter systems.

The dorsal raphe nucleus (DRN) is a serotoninergic center involved in physiological functions related to cognition, mood, and emotion. Glutamatergic hyperstimulation (e.g., under stress conditions), increasing 5-HT content, and the subsequent deficit at limbic projections have been considered as potential mechanisms that underlie depression conditions [91]. Thus, SSRI-induced inhibition of nAChRs expressed in DRN might decrease 5-HT content, thus alleviating this condition.

Figure 2 shows a scheme of a DRN serotoninergic neuron and its modulation by other neurotransmitter systems. Under normal conditions, glutamatergic excitatory afferents from pyramidal neurons of the mPFC directly activate the DRN, thus increasing extracellular 5-HT, which is, in turn, regulated by somatodendritic $5-\mathrm{HT}_{1 \mathrm{~A}}$ autoreceptors. Under stress conditions, however, glutamatergic neurotransmission is hyperactivated, flooding the DRN with 5-HT (i.e., so-called "5-HT flooding"), but attenuating 5-HT outflow. In fact, higher-than-normal levels of 5-hydroxyindoleacetic acid (5-HIAA; major 5-HT metabolite) have been found in the cerebrospinal fluid (CSF) of subjects with depression, corresponding to the 5-HT flooding hypothesis. An excessive stimulation of 5- $\mathrm{HT}_{2 \mathrm{~A}} \mathrm{Rs}$ in the mPFC increases glutamatergic input, whereas an excessive stimulation of postsynaptic $5-\mathrm{HT}_{1 \mathrm{~A}} \mathrm{Rs}$ in the hippocampus is associated with a deficit at corticolimbic projection sites, thus compromising neuroplastic processes. Since NE and histamine are also increased during stress, 5-HT neurons are inhibited by NE transmission from the locus coeruleus and by histaminergic transmission. 


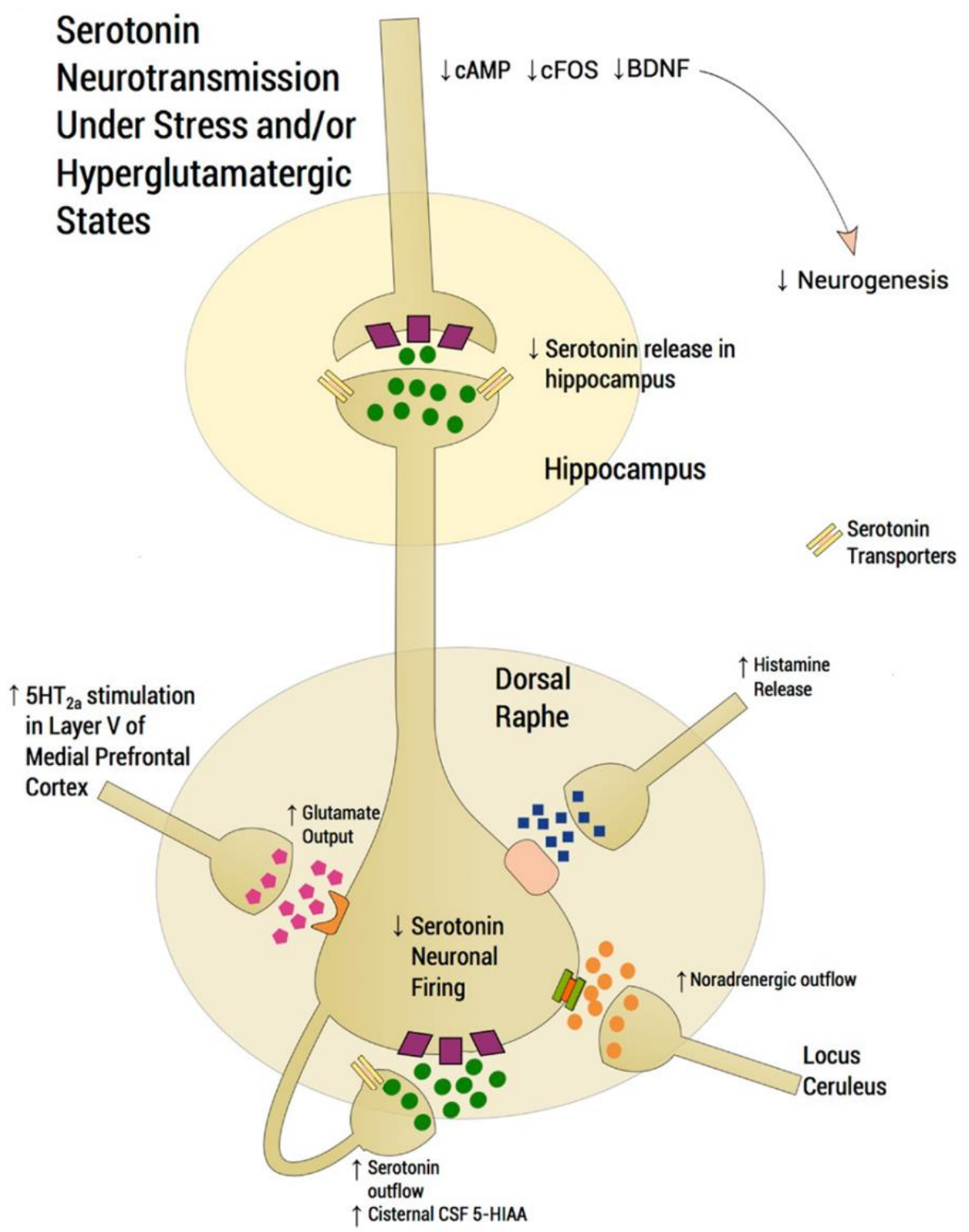

Figure 2. Scheme depicting the functioning of a dorsal raphe nucleus (DRN) serotoninergic neuron under stress conditions that induce depression disorders (modified from [91]). In normal conditions, glutamatergic excitatory afferents from pyramidal neurons of the medial prefrontal cortex (mPFC) directly activate the DRN, thus increasing extracellular serotonin (5-HT), which is regulated by somatodendritic $5-\mathrm{HT}_{1 \mathrm{~A}}$ autoreceptors, decreasing the excessive release in projection areas such as the $\mathrm{mPFC}$ and hippocampus. Under stress conditions, however, glutamatergic neurotransmission is hyperactivated, flooding the DRN with 5-HT (i.e., so-called "5-HT flooding"), but concomitantly attenuating 5-HT outflow. An excessive stimulation of $5-\mathrm{HT}_{2 \mathrm{~A}} \mathrm{Rs}$ in the $\mathrm{mPFC}$ increases glutamatergic input, whereas an excessive stimulation of postsynaptic $5-\mathrm{HT}_{1 \mathrm{~A}} \mathrm{Rs}$ in the hippocampus is associated with a deficit at corticolimbic projection sites, thus compromising neuroplastic processes. Based on this scheme, it is possible that SSRIs alleviate depression symptoms through two processes involving nAChRs: (1) inhibiting presynaptic nAChRs at glutamatergic afferents, which decreases 5-HT flooding to the DRN, and (2) inhibiting postsynaptic nAChRs, which attenuates DRN activity [7,92-94]. Since noradrenaline (NE) and histamine are also increased during stress/depression conditions, 5-HT neuron firing is inhibited by NE transmission from the locus coeruleus through $\alpha 2$-heteroceptors and by histamine transmission through histamine- 1 receptors. Serotonin transporters are located presynaptically. CSF: cerebrospinal fluid; 5-HIAA: 5-hydroxyindoleacetic acid. 
Experimental results indicated that $\sim 75 \%$ of the DRN neurons that project to the NAc, an area involved in brain reward, are serotoninergic, and are, in turn, modulated by $n A C h R s$ [90]. Activation (by nicotine) of postsynaptic nAChRs (i.e., $\alpha 4 \beta 2^{*}$ and $\alpha 7^{*}$ $n A C h R s)$ increased the firing frequency of DRN serotoninergic neurons, whereas activation of presynaptic $\alpha 4 \beta 2^{*}$ nAChRs augmented glutamate (Glu) release from excitatory glutamatergic afferents to the DRN [95-98]. Based on this scheme, it is possible that SSRIs alleviate depression symptoms through two processes (see Figure 2): (1) by inhibiting presynaptic nAChRs at glutamatergic afferents, which decreases 5-HT flooding at DRN neurons, and (2) by inhibiting postsynaptic nAChRs, which attenuates DRN activity. Activation of presynaptic $\alpha 4 \beta 2^{*}$ nAChRs also increased 5-HT release in serotoninergic projections to the NAc, which might be related to the anxiolytic and addictive activity of nicotine [93].

Other neurotransmitter systems modulated by nAChRs are also involved in depression, which adds to the complexity of SSRI-modulating actions. For instance, MDD is associated with reductions in inhibitory GABAergic transmission in the occipital cortex, anterior cingulate, and dorsomedial/dorsolateral PFC, as well as with an excessive increase in Glu release or changes in glutamate receptors (GluR )properties in the hippocampus and PFC $[7,93]$. There are contrasting explanations of how fluoxetine may improve information processing in these impaired neuronal networks. Komlósi et al. [94] suggested that fluoxetine can suppress excitatory glutamatergic transmission without changing the output of GABAergic neurons, whereas Van Dyke et al. [92] indicated that chronic fluoxetine potentiates excitatory synapses by activating $5-\mathrm{HT}_{1 \mathrm{~B}} \mathrm{Rs}$, and may induce deleterious effects, such as long-term depression and decreased long-term memory. On the other hand, Méndez et al. [99] concluded that acute fluoxetine decreases GABAergic transmission in the hippocampus through presynaptic mechanisms, independently of its effect on SERT. Interestingly, cholinergic signaling via nAChRs in pyramidal cells and GABAergic interneurons modulates inhibitory circuits in the hippocampus, which is crucial for information processing [100]. Different SSRIs inhibit hippocampal nAChRs (Table 1), and this activity disinhibits GABAergic neurons, finally improving the symptoms in MDD. In other words, SSRI-induced inhibition of nAChRs expressed in both glutamatergic and GABAergic neurons-regulating excitatory and inhibitory responses, respectively-is considered fundamental in maintaining neuronal circuit oscillations, which seem to be disrupted during depression [101].

The rostromedial tegmental (RMTg) nucleus, which contributes to monoaminergic responses to stressing events and is involved in depression, receives cholinergic inputs from the laterodorsal and pedunculopontine tegmental nuclei that activate presynaptic $\alpha 7 \mathrm{nAChRs,} \mathrm{thus} \mathrm{finally} \mathrm{increasing} \mathrm{Glu} \mathrm{release} \mathrm{in} \mathrm{the} \mathrm{lateral} \mathrm{habenula} \mathrm{(} \mathrm{LHb})$. The $\mathrm{LHb}$ has been considered to play a role in the development of pain and depression, two highly prevalent disorders that coexist in $\sim 60 \%$ of patients [102]. In turn, RMTg neurons exert an inhibitory effect mediated by GABA on dopaminergic neurons in the ventral tegmental area (VTA), which is part of the brain reward system [103,104]. In the VTA, nicotine increased postsynaptic current amplitude, which was blocked by methyllycaconitine, indicating the involvement of $\alpha 7 \mathrm{nAChRs}$ in the reward mechanism [103]. Based on this scenario, it is possible to suggest that SSRIs, by inhibiting $\alpha 7 \mathrm{nAChRs}$, may decrease the inhibitory activity of GABAergic neurons in the reward system.

The $\mathrm{LHb}$ is connected to the limbic system, whereas the medial habenula (MHb) is connected to the interpeduncular nucleus. The habenulo-interpeduncular pathway is considered a second — not the least important—reward circuitry that modulates, directly and indirectly, the mesolimbic dopaminergic reward system. Interestingly, this cholinergic pathway is a major player in the aversive effects of nicotine [103,104]. In particular, the $\mathrm{MHb}$ expresses $\alpha 3 \beta 4^{*}$ nAChRs, which are considered targets for the anti-addictive activity of coronaridine congeners, including natural alkaloids, such as ibogaine and its active metabolite noribogaine, and the synthetic derivative 18-methoxycoronaridine. Our functional results showed that both coronaridine alkaloids and synthetic derivatives noncompetitively inhibit $\alpha 3 \beta 4 \mathrm{nAChRs}$ expressed in heterologous cells and the MHb [105,106]. 
It has been demonstrated that ibogaine and noribogaine induce antidepressant-like activity in rodents [107], probably through inhibition of habenular $\alpha 3 \beta 4^{*} \mathrm{nAChRs}$. Since citalopram also inhibits habenular $\alpha 3 \beta 4^{*} \mathrm{nAChRs} \mathrm{[68]} \mathrm{(Table} \mathrm{1),} \mathrm{it} \mathrm{is} \mathrm{obvious} \mathrm{to} \mathrm{conclude} \mathrm{that}$ the observed inhibition may be involved, at least partially, in the clinical efficacy of SSRIs.

\section{SSRIs Bind Distinct nAChR Subtypes with Different Affinities}

Although we know that SSRIs inhibit different nAChR subtypes, the relationship between inhibitory potency, binding affinities, and clinical efficacy is less clear. Thus, the binding affinities of SSRIs and other antidepressants at various nAChRs in different conformational states were determined through radioligand competition experiments $[70,77,108,109]$. More specifically, the influence of several SSRIs on the maximal binding of either $\left[{ }^{3} \mathrm{H}\right]$ imipramine (a known tricyclic antidepressant and noncompetitive antagonist (NCA) of nAChRs $[71,110]$ ) to a variety of $n A C h R$ subtypes or $\left[{ }^{3} \mathrm{H}\right] \mathrm{TCP}$ (a known NCA of Torpedo nAChRs [111]) to Torpedo nAChRs in the resting (toxin-bound) and desensitized (agonist-bound) states was determined. The studied SSRIs completely inhibited the specific binding of both $\left[{ }^{3} \mathrm{H}\right]$ imipramine [77] and $\left[{ }^{3} \mathrm{H}\right] \mathrm{TCP}[70]$, respectively. The calculated binding affinities $\left(\mathrm{K}_{\mathrm{i}}\right)$ for desensitized $\mathrm{nAChRs}$ were generally higher than those in the resting state (Table 2). In the desensitized state, fluoxetine inhibited $\left[{ }^{3} \mathrm{H}\right]$ imipramine binding to $\alpha 4 \beta 2$ AChRs with higher affinity than with $\alpha 3 \beta 4$ ( $\sim$-fold) and $\alpha 7$ ( 10-fold) nAChRs, respectively (Table 2 ). Comparing the binding affinity of different SSRIs, the following rank order was determined $\left(\mathrm{K}_{\mathrm{i}}{ }^{\prime} \mathrm{s}\right.$ in $\left.\mu \mathrm{M}\right)$ for $\alpha 4 \beta 2$ : fluoxetine $(1.0 \pm 0.1)>$ citalopram $(4.1 \pm 0.3)$ $>$ paroxetine $(6.7 \pm 0.9)$, and for $\alpha 3 \beta 4$ : citalopram $(1.8 \pm 0.1)>$ fluoxetine $(4.8 \pm 0.5)>$ paroxetine $(6.9 \pm 0.6)$, respectively (Table 2$)$. These results support a direct interaction of SSRIs with NCA sites located in the nAChR ion channel (see Section 10).

Table 2. Binding affinities $\left(\mathrm{K}_{\mathrm{i}}\right)$ of SSRIs with resting and desensitized nAChRs.

\begin{tabular}{|c|c|c|c|c|c|}
\hline \multirow{2}{*}{ Radioligand } & \multirow{2}{*}{ nAChR Subtype } & \multirow{2}{*}{ SSRI } & \multicolumn{2}{|c|}{$K_{i}(\mu M)^{a}$} & \multirow[t]{2}{*}{ Reference } \\
\hline & & & Resting State & Desensitized State & \\
\hline \multirow{8}{*}[{}^{3}\mathrm{H}]{ Imipramine } & \multirow{3}{*}{$\mathrm{h} \alpha 4 \beta 2$} & Fluoxetine & $3.2 \pm 0.4$ & $1.0 \pm 0.1$ & [70] \\
\hline & & Paroxetine & $16.1 \pm 1.3$ & $6.7 \pm 0.9$ & [70] \\
\hline & & Citalopram & ND & $4.1 \pm 0.3$ & [68] \\
\hline & \multirow{3}{*}{$h \alpha 3 \beta 4$} & Citalopram & ND & $1.8 \pm 0.1$ & [68] \\
\hline & & Fluoxetine & $14.9 \pm 1.4$ & $4.8 \pm 0.5$ & [70] \\
\hline & & Paroxetine & $24.0 \pm 1.8$ & $6.9 \pm 0.6$ & [70] \\
\hline & \multirow[b]{2}{*}{$\mathrm{h} \alpha 7$} & Fluoxetine & $16.9 \pm 1.4$ & $11.0 \pm 1.0$ & [70] \\
\hline & & Paroxetine & $8.9 \pm 0.8$ & $8.7 \pm 0.6$ & [70] \\
\hline \multirow{2}{*}[{}^{3}\mathrm{H}]{$\mathrm{TCP}$} & Torpedo & Fluoxetine & $1.9 \pm 0.2$ & $0.96 \pm 0.04$ & [77] \\
\hline & $\alpha 1 \beta 1 \gamma \delta$ & Paroxetine & $34 \pm 2$ & $2.5 \pm 0.1$ & [77] \\
\hline
\end{tabular}

${ }^{a}$ The inhibition constant $\left(\mathrm{K}_{\mathrm{i}}\right)$ represents the ligand affinity for the tested radioligand binding site(s) in the desensitized (agonist-bound) and resting (bungarotoxin-bound) states, respectively. h, human.

\section{SSRIs Interact with $\mathrm{nAChRs}$ in Different Conformational States}

Although SSRIs generally inhibit $\mathrm{nAChRs}$ in a noncompetitive manner, the intrinsic inhibitory mechanisms are less clear. $\mathrm{nAChRs}$ exist in three allosteric transitions between different conformational states: a resting state, an active open-channel state, and several desensitized states, each with a non-conducting ion channel [38,112]. Even though the functional properties of SSRIs have not been studied on all existent nAChR subtypes and conformational states, the experimental evidence indicates that their activity is dependent on the conformational state. For instance, fluoxetine allosterically modulates nAChRs by interacting with the resting (closed), active (open), and desensitized (non-conducting) receptor states $[27,30,70]$. Particularly, fluoxetine promotes a faster $\mathrm{nAChR}$ desensitization and has stronger inhibitory potency at higher concentrations, suggesting a higher affinity to desensitized nAChRs $[26,77]$ in accordance with the radioligand binding results 
(Table 2). This pharmacological characteristic is common to other structurally different antidepressants [110], suggesting a shared mode of action.

While the pharmacological activity of fluoxetine with nAChRs is subtype- and statedependent, we can summarize its basic functional effects as follow: (a) Fluoxetine reduces the frequency of channel opening, (b) increases channel closed times, and (c) decreases channel open times, without (d) altering single-channel conductance [27,30]. Accordingly, fluoxetine activity at the whole-cell level results in increased $\mathrm{nAChR}$ desensitization and the reduction of agonist-induced current amplitude, ultimately reducing $\mathrm{Ca}^{2+}$ entry $[27,30,69]$.

Based on this evidence, we can suggest a probable mechanism for the clinical activity of SSRIs. In depression conditions, where higher concentrations of ACh are expected, most $n A C h R s$ are likely in the desensitized state. As shown previously, this conformational (closed) state is powerfully inhibited by antidepressants and maintained for a longer time, thus synergistically reducing nAChR-related signaling, which may ultimately be beneficial for the improvement of MDD and other depression disorders.

\section{Characterization of SSRI Binding Sites for Different nAChR Subtypes}

Molecular docking simulations have been used to determine the molecular interactions of SSRIs with a variety of nAChR subtypes $[70,77,108,109,113,114]$. In this regard, based on the crystal structure of h $\alpha 4 \beta 2$ (PDB id: $5 \mathrm{KXI}$ ) [115] and Torpedo nAChR molecular models (PDB id: 2BG9) [116], several neuronal nAChRs were constructed, including the $\alpha 4 \beta 2$, $\alpha 3 \beta 4, \alpha 7$, and $\alpha 9 \alpha 10$ subtypes [68,70,108,109,113,117,118]. SSRIs and other antidepressants were subsequently docked to each $\mathrm{nAChR}$ model $[68,70,117,118]$, and molecular dynamics simulations were performed to determine the stability of each interaction.

Docking simulations indicated that fluoxetine interacts within the middle portion of the ion channel of each nAChR subtype, except the $\alpha 9 \alpha 10$ subtype. Considering that each subunit has one transmembrane M2 segment, the ion channel is formed by five M2 segments [119]. Although the ion channel is highly conserved among species, differences are also apparent among $\mathrm{nAChR}$ subunit sequences [119], producing variations in the $n A C h R$ ion channel structure. For example, in the $\alpha 4 \beta 2 \mathrm{nAChR}$ (Figure 3), the amino acid rings are named: outer or extracellular (position $20^{\prime}$ ), nonpolar (position $17^{\prime}$ ), valine (position $\left.13^{\prime}\right)$, leucine (position $\left.9^{\prime}\right)$, serine (position $\left.6^{\prime}\right)$, threonine (position $\left.2^{\prime}\right)$, intermediate (position $-2^{\prime}$ ), and cytoplasmic or inner (position $-5^{\prime}$ ), whereas in the $\alpha 7 \mathrm{nAChR}$, the polar rings (positions $2^{\prime}$ and $6^{\prime}$ ) are switched: The threonine ring occurs at position $6^{\prime}$, and the serine ring at position $2^{\prime}$.

The molecular docking of fluoxetine suggested that this molecule interacts with residues lining the channel lumen located between amino acid rings from position $6^{\prime}$ up to position $13^{\prime}$ of each studied nAChR subtype [70]. The orientations of docked fluoxetine in the $\alpha 4 \beta 2$ (Figure 3) and $\alpha 7$ [76] nAChR models are essentially the same. The amino group and the aromatic ring containing the trifluoromethyl moiety of fluoxetine interact through van der Waals contacts with valine residues at position $13^{\prime}$. Moreover, the oxygen atom forms a hydrogen bond with the hydroxyl group provided by the $\alpha 4$-Ser251 residue at position $10^{\prime}$ (Figure 3).

The docking orientation of fluoxetine in the $\alpha 3 \beta 4 \mathrm{nAChR}$ ion channel is slightly different because the $\alpha 4$ subunit carries additional phenylalanine residues at position $13^{\prime}$, forming the valine/phenylalanine ring together with an $\alpha 3$ subunit. In particular, the position of the fluoxetine aminoaryl moiety in this ion channel is exchanged with the benzyl ring position that was suggested in other $\mathrm{nAChR}$ subtypes. Thus, both aromatic rings of the molecule bind to the three phenylalanine residues at position $13^{\prime}$ (i.e., $\beta 4$-Phe253), probably through $\pi-\pi$ interactions [117]. 


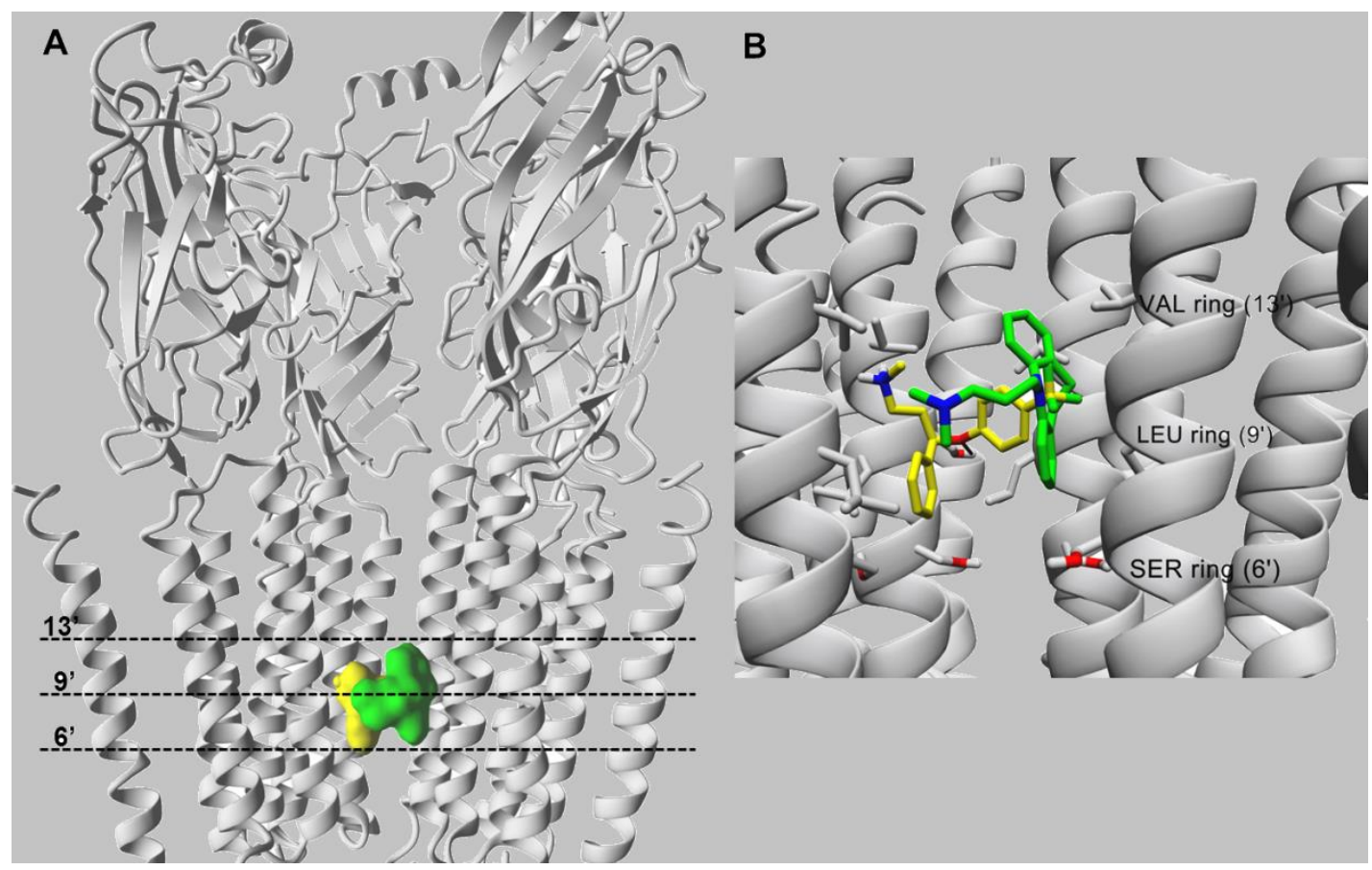

Figure 3. Molecular docking of fluoxetine (in yellow) and imipramine (in green), both in the protonated state, within the $\alpha 4 \beta 2 \mathrm{nAChR}$ ion channel (modified from [70]). (A) Side view of the overlapping binding sites for both ligands that interact with the middle portion of ion channel. (B) Imipramine (in green) and fluoxetine (in yellow) interact with the M2 transmembrane segments forming the lumen of the $\alpha 4 \beta 2 \mathrm{nAChR}$ ion channel. Both ligands interact mainly through van der Waals contacts with a domain formed between the valine (VAL) (position 13') and serine (SER) (position $6^{\prime}$ ) rings. In addition, the black arrow indicates the hydrogen bond formed between the oxygen atom of fluoxetine and the hydroxyl group of $\alpha 4$-Ser251 (position 10'). For clarity, one $\beta 2$ subunit is hidden. Residues involved in ligand binding are presented in stick mode (gray), whereas ligands are rendered either in the ball (A) or stick mode (B). All non-polar hydrogen atoms are hidden.

In the case of escitalopram (i.e., (S)-citalopram), two luminal binding sites at $\alpha 3 \beta 4$ nAChRs were characterized [68]. A high-affinity binding site was located between positions $5^{\prime}$ and $16^{\prime}$ - in the middle of the ion channel—-toward the extracellular ion channel's mouth (Figure 4A). In addition, a low-affinity binding site for escitalopram was located closer to the cytoplasmic side, between positions $-3^{\prime}$ and $6^{\prime}$. Although the high-affinity site corresponds to that found for fluoxetine in the $\alpha 3 \beta 4 \mathrm{nAChR}$ (see above), few differences between both antidepressants were detected. For instance, escitalopram, but not fluoxetine, established a cation $-\pi$ interaction with $\alpha 3-\mathrm{F} 255$ (position $14^{\prime}$ ) and interacted with $\beta 4$-T254 (position 12') (Figure 4B). Interestingly, fluoxetine formed a $\pi-\pi$ interaction with $\beta 4$-Phe255 (position 13'), which coincides with that for coronaridine congeners [105]. The binding site for coronaridine congeners, located between positions $6^{\prime}$ and $13^{\prime}$ [105], overlaps with the site for SSRIs.

Since fluoxetine displaced $\left[{ }^{3} \mathrm{H}\right]$ imipramine binding to different nAChRs (Table 2), the molecular docking of imipramine was compared to that for fluoxetine at both $\alpha 4 \beta 2$ and $\alpha 3 \beta 4 \mathrm{nAChRs}[70,117]$. The results suggested that imipramine interacts with a site located in the middle portion of the ion channel. A more detailed analysis indicated that in the case of $\alpha 4 \beta 2 \mathrm{nAChRs}$, imipramine interacts with residues that form the valine and leucine, but not the serine, rings via van der Waals contacts [118], whereas in the $\alpha 3 \beta 4 \mathrm{nAChR}$, imipramine interacts with several residues between the valine/phenylalanine (e.g., its aromatic rings form $\pi-\pi$ interactions with three $\beta 4$-Phe253 residues at position $13^{\prime}$ ) and leucine rings [117]. These docking results agree with radioligand binding data, suggesting that the SSRI binding site in different nAChR subtypes overlaps the imipramine locus in both desensitized and resting states [70,77]. 


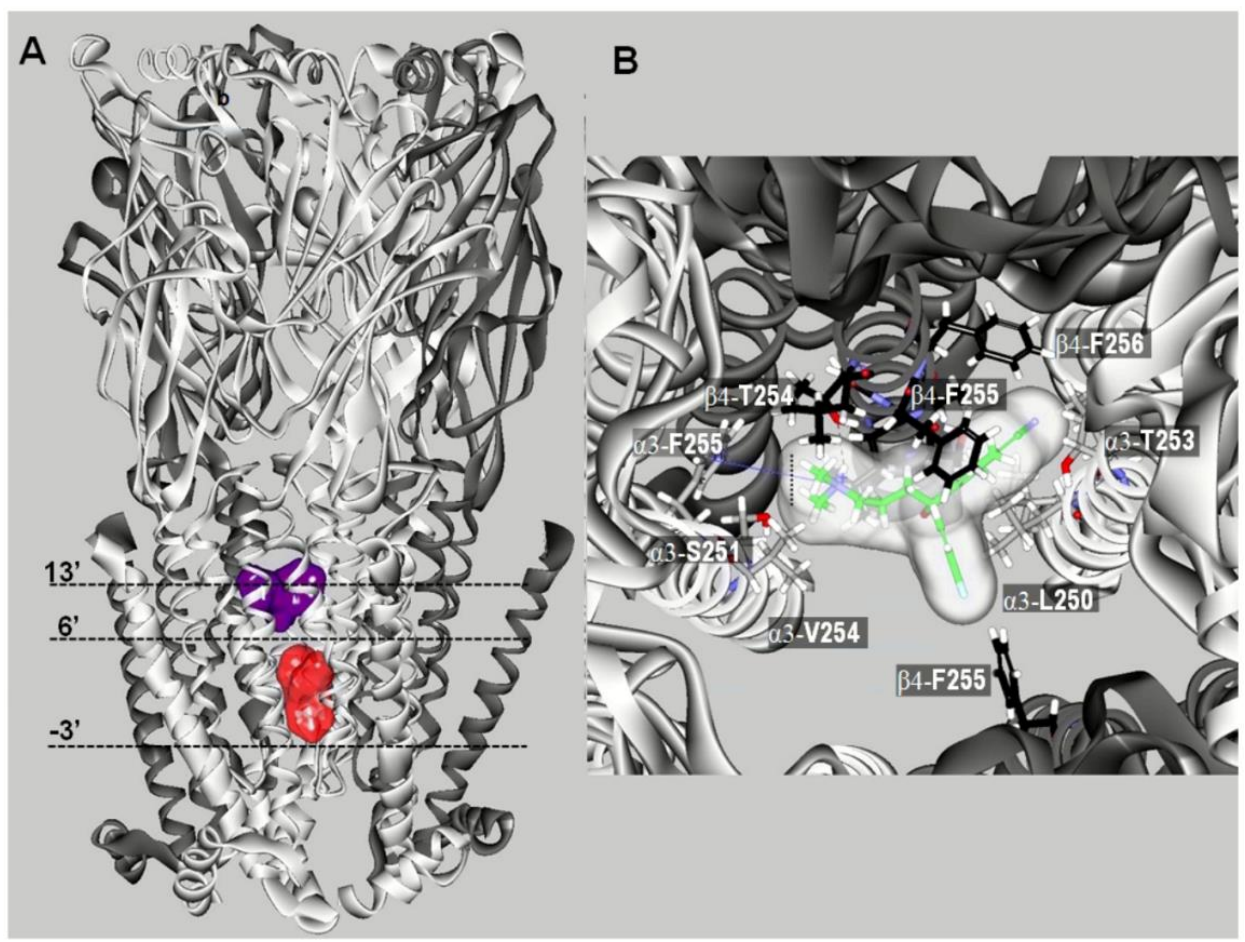

Figure 4. Docking sites for S-(+)-citalopram (escitalopram) in the $(\alpha 3)_{3}(\beta 4)_{2} \mathrm{nAChR}$ model (modified from [68]). (A) Escitalopram docked at two luminal sites (surface model): a high-affinity site located closer to the extracellular ion channel's mouth (blue) and a low-affinity site located closer to the cytoplasmic side (red). The $\alpha 3$ (white) and $\beta 4$ (dark gray) subunits are represented as solid ribbons. Dotted lines indicate the positions of the Gly (position $-3^{\prime}$ ), Ser (position $6^{\prime}$ ), and Val (position $13^{\prime}$ ) rings along the ion channel. (B) Detailed view of escitalopram at the high-affinity luminal site, showing the cation $-\pi$ interaction with $\alpha 3-F 255$ (position $1^{\prime}{ }^{\prime}$ ) and the interaction with $\beta 4-\mathrm{T} 254$ (position $12^{\prime}$ ).

Additional molecular docking studies using the $\alpha 9 \alpha 10 \mathrm{nAChR}$ model indicated that escitalopram interacts with orthosteric binding sites, but not with luminal sites [68] (Figure 5A).

So far, this is the only nAChR subtype where the SSRI-induced inhibition is mediated by a competitive mechanism. The orthosteric sites for escitalopram are located at the interface between $\alpha 10(+)$ (principal component) and $\alpha 9(-)$ or another $\alpha 10(-)$ (complementary component), but not at the $\alpha 9(+)$ and $\alpha 10(-)$ interface [68]. To study these interactions in more details, in silico mutations were performed on key residues at the orthosteric binding site, transforming $\alpha 9 \alpha 10$ into $\alpha 3 \beta 4$ and vice versa. The docking results indicated that the mutations did not abolish escitalopram binding to the $\alpha 9 \alpha 10$ mutant or enable escitalopram binding to the $\alpha 3 \beta 4$ mutant. To further investigate these intriguing findings, the role of the $\beta 9-\beta 10$ loop was assessed. In this regard, the orthosteric binding sites from $\alpha 3, \alpha 9$, and $\alpha 10$ were superposed with escitalopram docked at $\alpha 10(+)$ (Figure 5B). The superposition showed that the $\beta 9-\beta 10$ loop, which contains the Cys pair typical of $\alpha$-subunits, is widely open in $\alpha 10$, allowing escitalopram to fit into the binding site [68]. This loop is closer to the binding pocket in $\alpha 9$, and even closer in $\alpha 3$, compared to $\alpha 10$, causing escitalopram to overlap with the main-chain atoms of these subunits when it is docked to $\alpha 10(+)$. Additional structural details may support the observed differences. More specifically, $\alpha 10-\mathrm{R} 186 \mathrm{might}$ force the $\beta 9-\beta 10$ loop in $\alpha 10$ to be set apart from the receptor agonist pocket (Figure $5 \mathrm{C}$ ). Looking from the $\beta 9$ sheet (Figure 5D), the positively charged $\alpha 10-\mathrm{R} 186$ - in its extended mode in the model—points to the middle of the $\beta 9-\beta 10$ loop, contrary to the homologous hydrophobic $\alpha 9$-V186 and $\alpha 3-Y 184$ residues. The homologous position at $\alpha 7 \mathrm{nAChRs}$ is another positively charged residue, $\alpha 7-\mathrm{K} 182$, but unlike to $\alpha 10-\mathrm{R} 186$, it is readily de- 
protonated when partially buried within proteins $[120,121]$. These structural differences might account for a unique orthosteric binding pocket at $\alpha 9 \alpha 10 \mathrm{nAChRs,} \mathrm{which} \mathrm{allows} \mathrm{the}$ accommodation of molecules larger than nicotine or Ach, as observed in $\alpha 10$ (Figure 5C). At the ion channel level, however, there is no structural difference that might explain the absence of SSRI-induced $\alpha 9 \alpha 10 \mathrm{nAChR}$ ion channel blockade. It might be the case that an initial competitive inhibition of $\alpha 9 \alpha 10 \mathrm{nAChR}$ prevails over channel blocking, but the latter mechanism can be reached at higher concentrations, as suggested in the experimental studies [68].

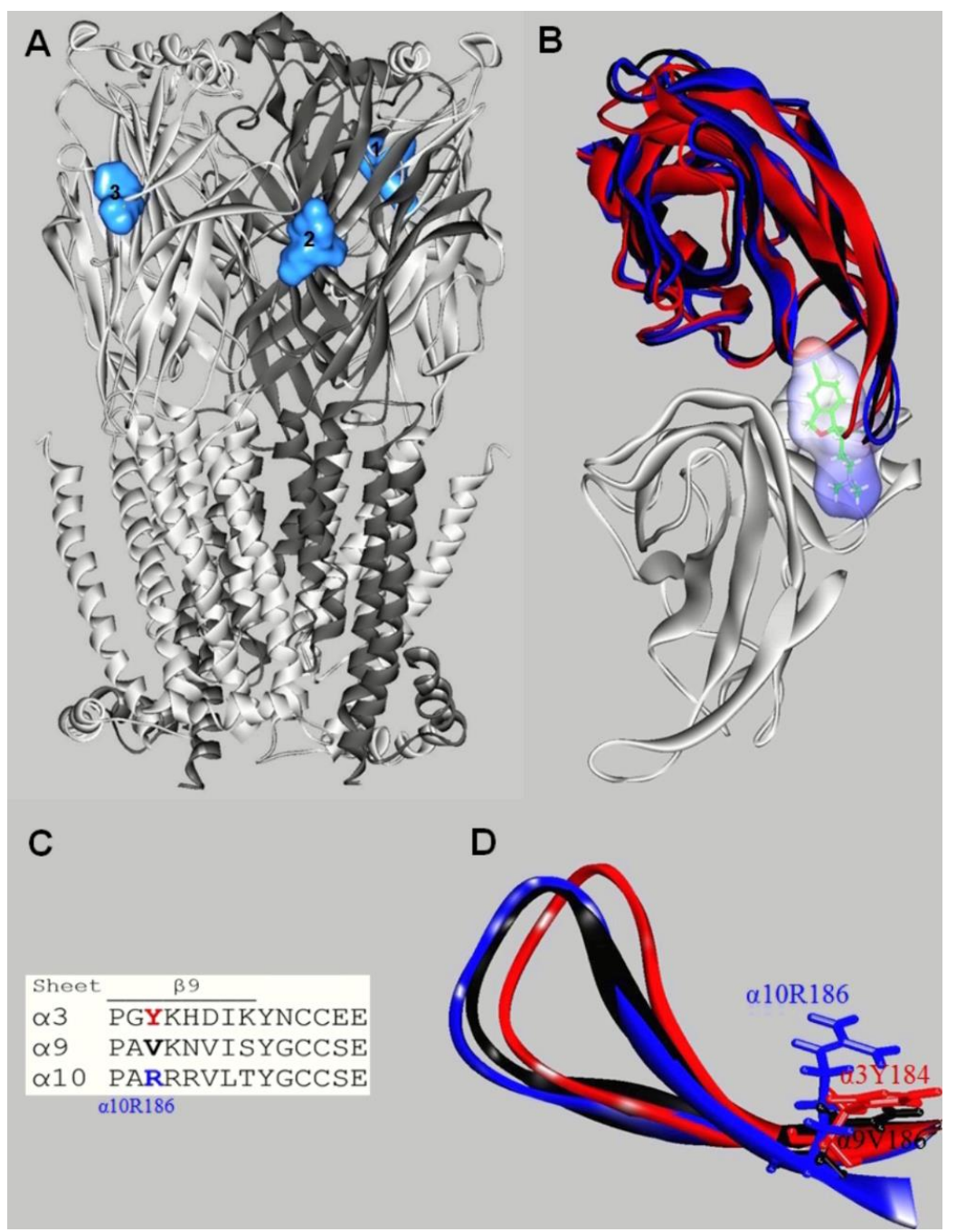

Figure 5. Docking sites for S-(+)-citalopram (escitalopram) in the $h(\alpha 9) 2(\alpha 10) 3 n A C h R$ model (modified from [68]). (A) Escitalopram (light blue surface model) interacted with three possible orthosteric sites located at the interface between the $\alpha 10(+)$ (principal component) and $\alpha 9(-)$ (or another $\alpha 10(-))$ (complementary component) subunits. The $\alpha 10$ (white) and $\alpha 9$ (dark gray) subunits are represented as solid ribbons. (B) Orthosteric binding sites at the superposed $\alpha 3(+)$ (red), $\alpha 9(+)$ (black), $\alpha 10(+)$ (blue), and $\alpha 9(-)$ (white) subunits. Escitalopram is shown as sticks surrounded by the molecular surface. The $\beta 9-\beta 10$ loop at the $\alpha 3$ and $\alpha 9$ subunits is closer to the receptor center than that at $\alpha 10$, and consequently, there is no room for escitalopram to fit in the agonist binding site in $\alpha 3$ and $\alpha 9$. The $\alpha 3$ - and $\alpha 9-\beta 9-\beta 10$ loops overlap the ligand when it is docked as in the $\alpha 9 \alpha 10$ receptor. (C) Amino acid sequence comparison between $\alpha 3, \alpha 9$, and $\alpha 10$ subunits at the level of the $\beta 9-\beta 10$ loop. Blue: Amino acids identified as causing different $\beta 9-\beta 10$ loop conformations. (D) Side-chain view showing differences in the occupied volume of side chains at the $\alpha 10-R 186, \alpha 9-\mathrm{V} 186$, and $\alpha 3-Y 184$ positions, respectively. The side-chain volume differences in the $\beta 9$-sheet would force the $\alpha 10-\beta 9-\beta 10$ loop to be set apart from the binding pocket. 


\section{Concluding Remarks}

Mounting evidence supports the idea that the therapeutic activity of many commonly used antidepressants, including SSRIs, is partially mediated through the inhibition of nAChRs, thus counteracting the overactivity of the cholinergic system, which leads to depressive symptoms. New data highlight the importance of $n A C h R s$ expressed in different neuronal pathways in the regulation of 5-HT-induced effects. DRN serotoninergic neurons have been studied with enough detail to ascribe a potential modulatory activity of nAChRs, especially under stress/depression conditions. The evidence that SSRIs also inhibit a variety of nAChRs expressed in different neurotransmitter systems increases the complexity by which these antidepressants may act clinically. Although "nicotinic modulation" of depression has been indirectly recognized, the development of specific ligands, such as inverse agonists and partial agonists, of therapeutic value is still lacking.

Author Contributions: H.R.A., K.M.T.-D., and J.G.-C. equally contributed to the writing: original draft preparation, review, and editing. M.O.O., writing-review and editing. All authors have read and agreed to the published version of the manuscript.

Funding: This research was funded by the Dirección General de Asuntos del Personal Académico (DGAPA), UNAM, México: PAPIIT-IN202420 and PASPA (to J.G.-C.), National Science Center, Poland (SONATA funding, UMO-2013/09/D/NZ7/04549) (to K.M.T-D. (PI) and H.R.A. (Co-PI)), and by an OVPR Pilot/Seed Grant (OSU-CHS) (to H.R.A.).

Institutional Review Board Statement: Not applicable.

Informed Consent Statement: Not applicable.

Data Availability Statement: The data presented in this study are available on request from the corresponding author.

Acknowledgments: We are grateful to Elizabeth Vázquez-Gómez for the technical assistance.

Conflicts of Interest: The authors declare no conflict of interest. The funders had no role in the design of the study; in the collection, analyses, or interpretation of data; in the writing of the manuscript, or in the decision to publish the results.

\section{References}

1. DSM-IV. Diagnostic and Statistical Manual of Mental Disorders IV-TR; American Psychiatric Press: Washington, DC, USA, 2020.

2. Duman, R.S.; Aghajanian, G.K. Synaptic Dysfunction in Depression: Potential Therapeutic Targets. Science 2012, 338, 68-72. [CrossRef]

3. Salerian, A.J.; Altar, C.A. The Prefrontal Cortex Influence over Subcortical and Limbic Regions Governs Antidepressant Response by $\mathrm{N}=\mathrm{H} /(\mathrm{M}+\mathrm{R})$. Psychiatry Res. 2012, 204, 1-12. [CrossRef]

4. Zurkovsky, L.; Taylor, W.D.; Newhouse, P.A. Cognition as a Therapeutic Target in Late-Life Depression: Potential for Nicotinic Therapeutics. Biochem. Pharmacol. 2013, 86, 1133-1144. [CrossRef] [PubMed]

5. Pandya, M.; Altinay, M.; Malone, D.A.; Anand, A. Where in the Brain Is Depression? Curr. Psychiatry Rep. 2012, 14, 634-642. [CrossRef]

6. Drago, A.; Crisafulli, C.; Sidoti, A.; Serretti, A. The Molecular Interaction between the Glutamatergic, Noradrenergic, Dopaminergic and Serotoninergic Systems Informs a Detailed Genetic Perspective on Depressive Phenotypes. Prog. Neurobiol. 2011, 94, 418-460. [CrossRef]

7. Pacher, P.; Kecskemeti, V. Trends in the Development of New Antidepressants. Is There a Light at the End of the Tunnel? Curr. Med. Chem. 2004, 11, 925-943. [CrossRef]

8. Goldberg, J.S.; Bell, C.E.; Pollard, D.A. Revisiting the Monoamine Hypothesis of Depression: A New Perspective. Perspect. Med. Chem. 2014, 6, 1-8. [CrossRef]

9. Ferguson, J.T. Treatment of Reserpine-Induced Depression with a New Analeptic: Phenidylate. Ann. N. Y. Acad. Sci. 1955, 61, 101-107. [CrossRef]

10. Freis, E.D. Mental Depression in Hypertensive Patients Treated for Long Periods with Large Doses of Reserpine. N. Engl. J. Med. 1954, 251, 1006-1008. [CrossRef]

11. Janowsky, D.S.; el-Yousef, M.K.; Davis, J.M.; Sekerke, H.J. A Cholinergic-Adrenergic Hypothesis of Mania and Depression. Lancet 1972, 2, 632-635. [CrossRef]

12. Levin, E.D. Complex Relationships of Nicotinic Receptor Actions and Cognitive Functions. Biochem. Pharmacol. 2013, 86, 1145-1152. [CrossRef] 
13. Kenney, J.W.; Gould, T.J. Modulation of Hippocampus-Dependent Learning and Synaptic Plasticity by Nicotine. Mol. Neurobiol. 2008, 38, 101-121. [CrossRef]

14. Mineur, Y.S.; Picciotto, M.R. Nicotine Receptors and Depression: Revisiting and Revising the Cholinergic Hypothesis. Trends Pharmacol. Sci. 2010, 31, 580-586. [CrossRef]

15. Shytle, R.D.; Silver, A.A.; Lukas, R.J.; Newman, M.B.; Sheehan, D.V.; Sanberg, P.R. Nicotinic Acetylcholine Receptors as Targets for Antidepressants. Mol. Psychiatry 2002, 7, 525-535. [CrossRef]

16. Steingard, R.J.; Yurgelun-Todd, D.A.; Hennen, J.; Moore, J.C.; Moore, C.M.; Vakili, K.; Young, A.D.; Katic, A.; Beardslee, W.R.; Renshaw, P.F. Increased Orbitofrontal Cortex Levels of Choline in Depressed Adolescents as Detected by in Vivo Proton Magnetic Resonance Spectroscopy. Biol. Psychiatry 2000, 48, 1053-1061. [CrossRef]

17. Janowsky, D.S.; el-Yousef, M.K.; Davis, J.M. Acetylcholine and Depression. Psychosom. Med. 1974, 36, 248-257. [CrossRef]

18. Risch, S.C.; Cohen, R.M.; Janowsky, D.S.; Kalin, N.H.; Murphy, D.L. Mood and Behavioral Effects of Physostigmine on Humans Are Accompanied by Elevations in Plasma Beta-Endorphin and Cortisol. Science 1980, 209, 1545-1546. [CrossRef]

19. Risch, S.C.; Cohen, R.M.; Janowsky, D.S.; Kalin, N.H.; Sitaram, N.; Gillin, J.C.; Murphy, D.L. Physostigmine Induction of Depressive Symptomatology in Normal Human Subjects. Psychiatry Res. 1981, 4, 89-94. [CrossRef]

20. Mineur, Y.S.; Obayemi, A.; Wigestrand, M.B.; Fote, G.M.; Calarco, C.A.; Li, A.M.; Picciotto, M.R. Cholinergic Signaling in the Hippocampus Regulates Social Stress Resilience and Anxiety- and Depression-like Behavior. Proc. Natl. Acad. Sci. USA 2013, 110, 3573-3578. [CrossRef]

21. Dailey, J.W.; Yan, Q.S.; Mishra, P.K.; Burger, R.L.; Jobe, P.C. Effects of Fluoxetine on Convulsions and on Brain Serotonin as Detected by Microdialysis in Genetically Epilepsy-Prone Rats. J. Pharmacol. Exp. Ther. 1992, 260, 533-540.

22. Perry, K.W.; Fuller, R.W. Effect of Fluoxetine on Serotonin and Dopamine Concentration in Microdialysis Fluid from Rat Striatum. Life Sci. 1992, 50, 1683-1690. [CrossRef]

23. Nagayasu, K.; Kitaichi, M.; Nishitani, N.; Asaoka, N.; Shirakawa, H.; Nakagawa, T.; Kaneko, S. Chronic Effects of Antidepressants on Serotonin Release in Rat Raphe Slice Cultures: High Potency of Milnacipran in the Augmentation of Serotonin Release. Int. J. Neuropsychopharmacol. 2013, 16, 2295-2306. [CrossRef]

24. Elhwuegi, A.S. Central Monoamines and Their Role in Major Depression. Prog. Neuropsychopharmacol. Biol. Psychiatry 2004, 28, 435-451. [CrossRef]

25. Fitzgerald, K.T.; Bronstein, A.C. Selective Serotonin Reuptake Inhibitor Exposure. Top. Companion Anim. Med. 2013, 28 , 13-17. [CrossRef] [PubMed]

26. García-Colunga, J.; Miledi, R. Blockage of Mouse Muscle Nicotinic Receptors by Serotonergic Compounds. Exp. Physiol. 1999, 84, 847-864. [CrossRef] [PubMed]

27. García-Colunga, J.; Awad, J.N.; Miledi, R. Blockage of Muscle and Neuronal Nicotinic Acetylcholine Receptors by Fluoxetine (Prozac). Proc. Natl. Acad. Sci. USA 1997, 94, 2041-2044. [CrossRef]

28. Gunasekara, N.S.; Noble, S.; Benfield, P. Paroxetine. An Update of Its Pharmacology and Therapeutic Use in Depression and a Review of Its Use in Other Disorders. Drugs 1998, 55, 85-120. [CrossRef] [PubMed]

29. Wong, D.T.; Bymaster, F.P.; Engleman, E.A. Prozac (Fluoxetine, Lilly 110140), the First Selective Serotonin Uptake Inhibitor and an Antidepressant Drug: Twenty Years since Its First Publication. Life Sci. 1995, 57, 411-441. [CrossRef]

30. Deflorio, C.; Catalano, M.; Fucile, S.; Limatola, C.; Grassi, F. Fluoxetine Prevents Acetylcholine-Induced Excitotoxicity Blocking Human Endplate Acetylcholine Receptor. Muscle Nerve 2014, 49, 90-97. [CrossRef]

31. Staley, J.K.; Krishnan-Sarin, S.; Cosgrove, K.P.; Krantzler, E.; Frohlich, E.; Perry, E.; Dubin, J.A.; Estok, K.; Brenner, E.; Baldwin, R.M.; et al. Human Tobacco Smokers in Early Abstinence Have Higher Levels of $\beta 2^{*}$ Nicotinic Acetylcholine Receptors than Nonsmokers. J. Neurosci. 2006, 26, 8707-8714. [CrossRef]

32. Chaouch, A.; Müller, J.S.; Guergueltcheva, V.; Dusl, M.; Schara, U.; Rakocević-Stojanović, V.; Lindberg, C.; Scola, R.H.; Werneck, L.C.; Colomer, J.; et al. A Retrospective Clinical Study of the Treatment of Slow-Channel Congenital Myasthenic Syndrome. J. Neurol. 2012, 259, 474-481. [CrossRef]

33. Bliziotes, M.; Eshleman, A.; Burt-Pichat, B.; Zhang, X.-W.; Hashimoto, J.; Wiren, K.; Chenu, C. Serotonin Transporter and Receptor Expression in Osteocytic MLO-Y4 Cells. Bone 2006, 39, 1313-1321. [CrossRef]

34. Nencetti, S.; Demontis, G.C.; Mazzoni, M.R.; Betti, L.; Banti, I.; Rossello, A.; Lapucci, A. 3-[(Aryl)(4-Fluorobenzyloxy)Methyl]Piperidine Derivatives: High-Affinity Ligands for the Serotonin Transporter. J. Pharm. Pharmacol. 2007, 59, 1439-1445. [CrossRef]

35. Wang, S.; Chen, Y.; Liu, X.; Xu, X.; Liu, X.; Liu, B.-F.; Zhang, G. Synthesis and Evaluation of Novel 2,3-Dihydrobenzo[b][1,4]Dioxinand Indolealkylamine Derivatives as Potential Antidepressants. Arch. Pharm. 2014, 347, 32-41. [CrossRef]

36. Lendvai, B.; Vizi, E.S. Nonsynaptic Chemical Transmission through Nicotinic Acetylcholine Receptors. Physiol. Rev. 2008, 88, 333-349. [CrossRef]

37. Marchi, M.; Grilli, M. Presynaptic Nicotinic Receptors Modulating Neurotransmitter Release in the Central Nervous System: Functional Interactions with Other Coexisting Receptors. Prog. Neurobiol. 2010, 92, 105-111. [CrossRef] [PubMed]

38. Changeux, J.-P. The Nicotinic Acetylcholine Receptor: The Founding Father of the Pentameric Ligand-Gated Ion Channel Superfamily. J. Biol. Chem. 2012, 287, 40207-40215. [CrossRef] [PubMed]

39. Yakel, J.L. Cholinergic Receptors: Functional Role of Nicotinic ACh Receptors in Brain Circuits and Disease. Pflüg. Arch. Eur. J. Physiol. 2013, 465, 441-450. [CrossRef] [PubMed] 
40. Picciotto, M.R.; Mineur, Y.S. Molecules and Circuits Involved in Nicotine Addiction: The Many Faces of Smoking. Neuropharmacology 2014, 76 Pt B, 545-553. [CrossRef]

41. Picciotto, M.R.; Brunzell, D.H.; Caldarone, B.J. Effect of Nicotine and Nicotinic Receptors on Anxiety and Depression. Neuroreport 2002, 13, 1097-1106. [CrossRef] [PubMed]

42. Saricicek, A.; Esterlis, I.; Maloney, K.H.; Mineur, Y.S.; Ruf, B.M.; Muralidharan, A.; Chen, J.I.; Cosgrove, K.P.; Kerestes, R.; Ghose, S.; et al. Persistent $\beta 2{ }^{*}$-Nicotinic Acetylcholinergic Receptor Dysfunction in Major Depressive Disorder. Am. J. Psychiatry 2012, 169, 851-859. [CrossRef]

43. Hannestad, J.O.; Cosgrove, K.P.; DellaGioia, N.F.; Perkins, E.; Bois, F.; Bhagwagar, Z.; Seibyl, J.P.; McClure-Begley, T.D.; Picciotto, M.R.; Esterlis, I. Changes in the Cholinergic System between Bipolar Depression and Euthymia as Measured with [123I]5IA Single Photon Emission Computed Tomography. Biol. Psychiatry 2013, 74, 768-776. [CrossRef]

44. Meyer, P.M.; Strecker, K.; Kendziorra, K.; Becker, G.; Hesse, S.; Woelpl, D.; Hensel, A.; Patt, M.; Sorger, D.; Wegner, F.; et al. Reduced $\alpha 4 \beta 2 *$-Nicotinic Acetylcholine Receptor Binding and Its Relationship to Mild Cognitive and Depressive Symptoms in Parkinson Disease. Arch. Gen. Psychiatry 2009, 66, 866-877. [CrossRef]

45. Andreasen, J.T.; Henningsen, K.; Bate, S.; Christiansen, S.; Wiborg, O. Nicotine Reverses Anhedonic-like Response and Cognitive Impairment in the Rat Chronic Mild Stress Model of Depression: Comparison with Sertraline. J. Psychopharmacol. Oxf. Engl. 2011, 25, 1134-1141. [CrossRef]

46. Andreasen, J.T.; Redrobe, J.P.; Nielsen, E.Ø. Combined $\alpha 7$ Nicotinic Acetylcholine Receptor Agonism and Partial Serotonin Transporter Inhibition Produce Antidepressant-like Effects in the Mouse Forced Swim and Tail Suspension Tests: A Comparison of SSR180711 and PNU-282987. Pharmacol. Biochem. Behav. 2012, 100, 624-629. [CrossRef]

47. Gentile, A.; Bianco, A.; Nordström, A.; Nordström, P. Use of Alcohol, Drugs, Inhalants, and Smoking Tobacco and the Long-Term Risk of Depression in Men: A Nationwide Swedish Cohort Study from 1969-2017. Drug Alcohol Depend. 2021, $221,108553$. [CrossRef]

48. Glassman, A.H.; Helzer, J.E.; Covey, L.S.; Cottler, L.B.; Stetner, F.; Tipp, J.E.; Johnson, J. Smoking, Smoking Cessation, and Major Depression. JAMA 1990, 264, 1546-1549. [CrossRef]

49. Kalman, D.; Morissette, S.B.; George, T.P. Co-Morbidity of Smoking in Patients with Psychiatric and Substance Use Disorders. Am. J. Addict. 2005, 14, 106-123. [CrossRef]

50. Mendelsohn, C. Smoking and Depression-A Review. Aust. Fam. Physician 2012, 41, 304-307.

51. Tsuang, M.T.; Francis, T.; Minor, K.; Thomas, A.; Stone, W.S. Genetics of Smoking and Depression. Hum. Genet. 2012, 131, 905-915. [CrossRef]

52. Piirtola, M.; Kaprio, J.; Baker, T.B.; Piasecki, T.M.; Piper, M.E.; Korhonen, T. The Associations of Smoking Dependence Motives with Depression among Daily Smokers. Addict. Abingdon Engl. 2021. [CrossRef] [PubMed]

53. Bacher, I.; Wu, B.; Shytle, D.R.; George, T.P. Mecamylamine-A Nicotinic Acetylcholine Receptor Antagonist with Potential for the Treatment of Neuropsychiatric Disorders. Expert Opin. Pharmacother. 2009, 10, 2709-2721. [CrossRef] [PubMed]

54. George, T.P.; Sacco, K.A.; Vessicchio, J.C.; Weinberger, A.H.; Shytle, R.D. Nicotinic Antagonist Augmentation of Selective Serotonin Reuptake Inhibitor-Refractory Major Depressive Disorder: A Preliminary Study. J. Clin. Psychopharmacol. 2008, 28, 340-344. [CrossRef] [PubMed]

55. Weinberger, A.H.; McKee, S.A.; Picciotto, M.R.; Mazure, C.M. Examining Antidepressant Drug Response by Smoking Status: Why Is It Important and How Often Is It Done? J. Psychopharmacol. Oxf. Engl. 2011, 25, 1269-1276. [CrossRef]

56. Belujon, P.; Grace, A.A. Dopamine System Dysregulation in Major Depressive Disorders. Int. J. Neuropsychopharmacol. 2017, 20, 1036-1046. [CrossRef]

57. Ortells, M.O.; Barrantes, G.E. Tobacco Addiction: A Biochemical Model of Nicotine Dependence. Med. Hypotheses 2010, 74, 884-894. [CrossRef] [PubMed]

58. Fenster, C.P.; Hicks, J.H.; Beckman, M.L.; Covernton, P.J.; Quick, M.W.; Lester, R.A. Desensitization of Nicotinic Receptors in the Central Nervous System. Ann. N. Y. Acad. Sci. 1999, 868, 620-623. [CrossRef]

59. Giniatullin, R.; Nistri, A.; Yakel, J.L. Desensitization of Nicotinic ACh Receptors: Shaping Cholinergic Signaling. Trends Neurosci. 2005, 28, 371-378. [CrossRef]

60. Cuevas-Olguin, R.; Esquivel-Rendon, E.; Vargas-Mireles, J.; Barajas-López, C.; Salgado-Delgado, R.; Saderi, N.; Arias, H.R.; Atzori, M.; Miranda-Morales, M. Nicotine Smoking Concentrations Modulate GABAergic Synaptic Transmission in Murine Medial Prefrontal Cortex by Activation of $\alpha 7^{*}$ and $\beta 2^{*}$ Nicotinic Receptors. Eur. J. Neurosci. 2020, 51, 781-792. [CrossRef]

61. Wanaverbecq, N.; Semyanov, A.; Pavlov, I.; Walker, M.C.; Kullmann, D.M. Cholinergic Axons Modulate GABAergic Signaling among Hippocampal Interneurons via Postsynaptic $\alpha 7$ Nicotinic Receptors. J. Neurosci. 2007, 27, 5683-5693. [CrossRef]

62. Hughes, J.R.; Stead, L.F.; Hartmann-Boyce, J.; Cahill, K.; Lancaster, T. Antidepressants for Smoking Cessation. Cochrane Database Syst. Rev. 2014, CD000031. [CrossRef] [PubMed]

63. Brown, R.A.; Abrantes, A.M.; Strong, D.R.; Niaura, R.; Kahler, C.W.; Miller, I.W.; Price, L.H. Efficacy of Sequential Use of Fluoxetine for Smoking Cessation in Elevated Depressive Symptom Smokers. Nicotine Tob. Res. 2014, 16, 197-207. [CrossRef] [PubMed]

64. Ribeiro, E.B.; Bettiker, R.L.; Bogdanov, M.; Wurtman, R.J. Effects of Systemic Nicotine on Serotonin Release in Rat Brain. Brain Res. 1993, 621, 311-318. [CrossRef] 
65. Redrobe, J.P.; Nielsen, E.Ø.; Christensen, J.K.; Peters, D.; Timmermann, D.B.; Olsen, G.M. $\alpha 7$ Nicotinic Acetylcholine Receptor Activation Ameliorates Scopolamine-Induced Behavioural Changes in a Modified Continuous Y-Maze Task in Mice. Eur. J. Pharmacol. 2009, 602, 58-65. [CrossRef]

66. Andreasen, J.T.; Nielsen, E.Ø.; Christensen, J.K.; Olsen, G.M.; Peters, D.; Mirza, N.R.; Redrobe, J.P. Subtype-Selective Nicotinic Acetylcholine Receptor Agonists Enhance the Responsiveness to Citalopram and Reboxetine in the Mouse Forced Swim Test. J. Psychopharmacol. Oxf. Engl. 2011, 25, 1347-1356. [CrossRef] [PubMed]

67. Popik, P.; Kozela, E.; Krawczyk, M. Nicotine and Nicotinic Receptor Antagonists Potentiate the Antidepressant-like Effects of Imipramine and Citalopram. Br. J. Pharmacol. 2003, 139, 1196-1202. [CrossRef]

68. Arias, H.R.; Jin, X.-T.; Gallino, S.; Peng, C.; Feuerbach, D.; García-Colunga, J.; Elgoyhen, A.B.; Drenan, R.M.; Ortells, M.O. Selectivity of $( \pm)$-Citalopram at Nicotinic Acetylcholine Receptors and Different Inhibitory Mechanisms between Habenular $\alpha 3 \beta 4^{*}$ and $\alpha 9 \alpha 10$ Subtypes. Neurochem. Int. 2019, 131, 104552. [CrossRef]

69. Chen, M.-F.; Huang, Y.-C.; Long, C.; Yang, H.-I.; Lee, H.-C.; Chen, P.-Y.; Hoffer, B.J.; Lee, T.J.-F. Bimodal Effects of Fluoxetine on Cerebral Nitrergic Neurogenic Vasodilation in Porcine Large Cerebral Arteries. Neuropharmacology 2012, 62, 1651-1658. [CrossRef]

70. Arias, H.R.; Feuerbach, D.; Targowska-Duda, K.M.; Russell, M.; Jozwiak, K. Interaction of Selective Serotonin Reuptake Inhibitors with Neuronal Nicotinic Acetylcholine Receptors. Biochemistry 2010, 49, 5734-5742. [CrossRef]

71. López-Valdés, H.E.; García-Colunga, J. Antagonism of Nicotinic Acetylcholine Receptors by Inhibitors of Monoamine Uptake. Mol. Psychiatry 2001, 6, 511-519. [CrossRef]

72. García-Colunga, J.; Vázquez-Gómez, E.; Miledi, R. Combined Actions of Zinc and Fluoxetine on Nicotinic Acetylcholine Receptors. Pharm. J. 2004, 4, 388-393. [CrossRef]

73. Fryer, J.D.; Lukas, R.J. Antidepressants Noncompetitively Inhibit Nicotinic Acetylcholine Receptor Function. J. Neurochem. 1999, 72, 1117-1124. [CrossRef] [PubMed]

74. Maggi, L.; Palma, E.; Miledi, R.; Eusebi, F. Effects of Fluoxetine on Wild and Mutant Neuronal $\alpha 7$ Nicotinic Receptors. Mol. Psychiatry 1998, 3, 350-355. [CrossRef] [PubMed]

75. Feuerbach, D.; Lingenhöhl, K.; Dobbins, P.; Mosbacher, J.; Corbett, N.; Nozulak, J.; Hoyer, D. Coupling of Human Nicotinic Acetylcholine Receptors $\alpha 7$ to Calcium Channels in GH3 Cells. Neuropharmacology 2005, 48, 215-227. [CrossRef]

76. Duarte, Y.; Rojas, M.; Canan, J.; Pérez, E.G.; González-Nilo, F.; García-Colunga, J. Different Classes of Antidepressants Inhibit the Rat $\alpha 7$ Nicotinic Acetylcholine Receptor by Interacting within the Ion Channel: A Functional and Structural Study. Molecules 2021, 26, 998. [CrossRef]

77. Arias, H.R.; Feuerbach, D.; Bhumireddy, P.; Ortells, M.O. Inhibitory Mechanisms and Binding Site Location for Serotonin Selective Reuptake Inhibitors on Nicotinic Acetylcholine Receptors. Int. J. Biochem. Cell Biol. 2010, 42, 712-724. [CrossRef] [PubMed]

78. Hennings, E.C.; Kiss, J.P.; De Oliveira, K.; Toth, P.T.; Vizi, E.S. Nicotinic Acetylcholine Receptor Antagonistic Activity of Monoamine Uptake Blockers in Rat Hippocampal Slices. J. Neurochem. 1999, 73, 1043-1050. [CrossRef]

79. Arias, H.R.; Vázquez-Gómez, E.; Hernández-Abrego, A.; Gallino, S.; Feuerbach, D.; Ortells, M.O.; Elgoyhen, A.B.; García-Colunga, J. Tricyclic Antidepressants Inhibit Hippocampal $\alpha 7^{*}$ and $\alpha 9 \alpha 10$ Nicotinic Acetylcholine Receptors by Different Mechanisms. Int. J. Biochem. Cell Biol. 2018, 100, 1-10. [CrossRef]

80. Peng, H.; Ferris, R.L.; Matthews, T.; Hiel, H.; Lopez-Albaitero, A.; Lustig, L.R. Characterization of the Human Nicotinic Acetylcholine Receptor Subunit alpha $(\alpha) 9$ (CHRNA9) and alpha $(\alpha) 10$ (CHRNA10) in Lymphocytes. Life Sci. 2004, 76, 263-280. [CrossRef]

81. Caiaffo, V.; Oliveira, B.D.R.; de Sá, F.B.; Evêncio Neto, J. Anti-inflammatory, Antiapoptotic, and Antioxidant Activity of Fluoxetine. Pharmacol. Res. Perspect. 2016, 4. [CrossRef]

82. Goodnick, P.J. Pharmacokinetics of Second Generation Antidepressants: Fluoxetine. Psychopharmacol. Bull. 1991, $27,503-512$. [PubMed]

83. Henry, M.E.; Schmidt, M.E.; Hennen, J.; Villafuerte, R.A.; Butman, M.L.; Tran, P.; Kerner, L.T.; Cohen, B.; Renshaw, P.F. A Comparison of Brain and Serum Pharmacokinetics of R-Fluoxetine and Racemic Fluoxetine: A 19-F MRS Study. Neuropsychopharmacology 2005, 30, 1576-1583. [CrossRef]

84. Karson, C.N.; Newton, J.E.; Livingston, R.; Jolly, J.B.; Cooper, T.B.; Sprigg, J.; Komoroski, R.A. Human Brain Fluoxetine Concentrations. J. Neuropsychiatry Clin. Neurosci. 1993, 5, 322-329. [PubMed]

85. Renshaw, P.F.; Guimaraes, A.R.; Fava, M.; Rosenbaum, J.F.; Pearlman, J.D.; Flood, J.G.; Puopolo, P.R.; Clancy, K.; Gonzalez, R.G. Accumulation of Fluoxetine and Norfluoxetine in Human Brain during Therapeutic Administration. Am. J. Psychiatry 1992, 149, 1592-1594.

86. Bolo, N.R.; Hodé, Y.; Nédélec, J.F.; Lainé, E.; Wagner, G.; Macher, J.P. Brain Pharmacokinetics and Tissue Distribution in Vivo of Fluvoxamine and Fluoxetine by Fluorine Magnetic Resonance Spectroscopy. Neuropsychopharmacology 2000, 23, 428-438. [CrossRef]

87. Nedahl, M.; Johansen, S.S.; Linnet, K. Reference Brain/Blood Concentrations of Citalopram, Duloxetine, Mirtazapine and Sertraline. J. Anal. Toxicol. 2018, 42, 149-156. [CrossRef] [PubMed]

88. Weber, M.L.; Hofland, C.M.; Shaffer, C.L.; Flik, G.; Cremers, T.; Hurst, R.S.; Rollema, H. Therapeutic Doses of Antidepressants Are Projected Not to Inhibit Human $\alpha 4 \beta 2$ Nicotinic Acetylcholine Receptors. Neuropharmacology 2013, 72, 88-95. [CrossRef] 
89. Yu, L.F.; Brek Eaton, J.; Zhang, H.K.; Sabath, E.; Hanania, T.; Li, G.N.; van Breemen, R.B.; Whiteaker, P.; Liu, Q.; Wu, J.; et al. The Potent and Selective $\alpha 4 \beta 2^{*} / \alpha 6^{*}$-Nicotinic Acetylcholine Receptor Partial Agonist 2-[5-[5-((S)Azetidin-2-Ylmethoxy)-3Pyridinyl]-3-Isoxazolyl]Ethanol Demonstrates Antidepressive-like Behavior in Animal Models and a Favorable ADME-Tox Profile. Pharmacol. Res. Perspect. 2014, 2, e00026. [CrossRef] [PubMed]

90. Dulawa, S.C.; Janowsky, D.S. Cholinergic Regulation of Mood: From Basic and Clinical Studies to Emerging Therapeutics. Mol. Psychiatry 2019, 24, 694-709. [CrossRef]

91. Coplan, J.D.; Gopinath, S.; Abdallah, C.G.; Berry, B.R. A Neurobiological Hypothesis of Treatment-Resistant DepressionMechanisms for Selective Serotonin Reuptake Inhibitor Non-Efficacy. Front. Behav. Neurosci. 2014, 8, 189. [CrossRef]

92. Van Dyke, A.M.; Francis, T.C.; Chen, H.; Bailey, A.M.; Thompson, S.M. Chronic Fluoxetine Treatment in Vivo Enhances Excitatory Synaptic Transmission in the Hippocampus. Neuropharmacology 2019, 150, 38-45. [CrossRef]

93. Luscher, B.; Shen, Q.; Sahir, N. The GABAergic Deficit Hypothesis of Major Depressive Disorder. Mol. Psychiatry 2011, 16, 383-406. [CrossRef] [PubMed]

94. Komlósi, G.; Molnár, G.; Rózsa, M.; Oláh, S.; Barzó, P.; Tamás, G. Fluoxetine (Prozac) and Serotonin Act on Excitatory Synaptic Transmission to Suppress Single Layer 2/3 Pyramidal Neuron-Triggered Cell Assemblies in the Human Prefrontal Cortex. J. Neurosci. 2012, 32, 16369-16378. [CrossRef]

95. Chang, B.; Daniele, C.A.; Gallagher, K.; Madonia, M.; Mitchum, R.D.; Barrett, L.; Vezina, P.; McGehee, D.S. Nicotinic Excitation of Serotonergic Projections from Dorsal Raphe to the Nucleus Accumbens. J. Neurophysiol. 2011, 106, 801-808. [CrossRef] [PubMed]

96. Galindo-Charles, L.; Hernandez-Lopez, S.; Galarraga, E.; Tapia, D.; Bargas, J.; Garduño, J.; Frías-Dominguez, C.; Drucker-Colin, R.; Mihailescu, S. Serotoninergic Dorsal Raphe Neurons Possess Functional Postsynaptic Nicotinic Acetylcholine Receptors. Synapse 2008, 62, 601-615. [CrossRef]

97. Garduño, J.; Galindo-Charles, L.; Jiménez-Rodríguez, J.; Galarraga, E.; Tapia, D.; Mihailescu, S.; Hernandez-Lopez, S. Presynaptic $\alpha 4 \beta 2$ Nicotinic Acetylcholine Receptors Increase Glutamate Release and Serotonin Neuron Excitability in the Dorsal Raphe Nucleus. J. Neurosci. 2012, 32, 15148-15157. [CrossRef] [PubMed]

98. Tucci, S.A.; Genn, R.F.; File, S.E. Methyllycaconitine (MLA) Blocks the Nicotine Evoked Anxiogenic Effect and 5-HT Release in the Dorsal Hippocampus: Possible Role of $\alpha 7$ Receptors. Neuropharmacology 2003, 44, 367-373. [CrossRef]

99. Méndez, P.; Pazienti, A.; Szabó, G.; Bacci, A. Direct Alteration of a Specific Inhibitory Circuit of the Hippocampus by Antidepressants. J. Neurosci. 2012, 32, 16616-16628. [CrossRef]

100. Griguoli, M.; Cherubini, E. Regulation of Hippocampal Inhibitory Circuits by Nicotinic Acetylcholine Receptors. J. Physiol. 2012, 590, 655-666. [CrossRef]

101. Chamberland, S.; Topolnik, L. Inhibitory Control of Hippocampal Inhibitory Neurons. Front. Neurosci. 2012, 6, 165. [CrossRef]

102. Zhang, G.-F.; Zhang, G.-F.; Zhang, G.-F. The Lateral Habenula: Role in Chronic Pain and Depression. Transl. Perioper. Pain Med. 2020, 7, 271-278.

103. Castillo-Rolón, D.; Ramírez-Sánchez, E.; Arenas-López, G.; Garduño, J.; Hernández-González, O.; Mihailescu, S.; Hernández-López, S. Nicotine Increases Spontaneous Glutamate Release in the Rostromedial Tegmental Nucleus. Front. Neurosci. 2020, 14, 604583. [CrossRef]

104. Elmer, G.I.; Palacorolla, H.; Mayo, C.L.; Brown, P.L.; Jhou, T.C.; Brady, D.; Shepard, P.D. The Rostromedial Tegmental Nucleus Modulates the Development of Stress-Induced Helpless Behavior. Behav. Brain Res. 2019, 359, 950-957. [CrossRef]

105. Arias, H.R.; Targowska-Duda, K.M.; Feuerbach, D.; Jozwiak, K. Coronaridine Congeners Inhibit Human $\alpha 3 \beta 4$ Nicotinic Acetylcholine Receptors by Interacting with Luminal and Non-Luminal Sites. Int. J. Biochem. Cell Biol. 2015, 65, 81-90. [CrossRef]

106. Arias, H.R.; Jin, X.; Feuerbach, D.; Drenan, R.M. Selectivity of Coronaridine Congeners at Nicotinic Acetylcholine Receptors and Inhibitory Activity on Mouse Medial Habenula. Int. J. Biochem. Cell Biol. 2017, 92, 202-209. [CrossRef]

107. Rodrı Guez, P.; Urbanavicius, J.; Prieto, J.P.; Fabius, S.; Reyes, A.L.; Havel, V.; Sames, D.; Scorza, C.; Carrera, I. A Single Administration of the Atypical Psychedelic Ibogaine or Its Metabolite Noribogaine Induces an Antidepressant-Like Effect in Rats. ACS Chem. Neurosci. 2020, 11, 1661-1672. [CrossRef]

108. Arias, H.R.; Fedorov, N.B.; Benson, L.C.; Lippiello, P.M.; Gatto, G.J.; Feuerbach, D.; Ortells, M.O. Functional and Structural Interaction of (-)-Reboxetine with the Human $\alpha 4 \beta 2$ Nicotinic Acetylcholine Receptor. J. Pharmacol. Exp. Ther. 2013, 344, 113-123. [CrossRef]

109. Arias, H.R.; Ortells, M.O.; Feuerbach, D. (-)-Reboxetine Inhibits Muscle Nicotinic Acetylcholine Receptors by Interacting with Luminal and Non-Luminal Sites. Neurochem. Int. 2013, 63, 423-431. [CrossRef]

110. Gumilar, F.; Arias, H.R.; Spitzmaul, G.; Bouzat, C. Molecular Mechanisms of Inhibition of Nicotinic Acetylcholine Receptors by Tricyclic Antidepressants. Neuropharmacology 2003, 45, 964-976. [CrossRef]

111. Arias, H.R.; Bhumireddy, P.; Bouzat, C. Molecular Mechanisms and Binding Site Locations for Noncompetitive Antagonists of Nicotinic Acetylcholine Receptors. Int. J. Biochem. Cell Biol. 2006, 38, 1254-1276. [CrossRef]

112. Calimet, N.; Simoes, M.; Changeux, J.-P.; Karplus, M.; Taly, A.; Cecchini, M. A Gating Mechanism of Pentameric Ligand-Gated Ion Channels. Proc. Natl. Acad. Sci. USA 2013, 110, E3987-E3996. [CrossRef]

113. Arias, H.R.; Feuerbach, D.; Targowska-Duda, K.M.; Aggarwal, S.; Lapinsky, D.J.; Jozwiak, K. Structural and Functional Interaction of $( \pm)$-2-(N-Tert-Butylamino)-3'-Iodo-4'-Azidopropiophenone, a Photoreactive Bupropion Derivative, with Nicotinic Acetylcholine Receptors. Neurochem. Int. 2012, 61, 1433-1441. [CrossRef] 
114. Arias, H.R.; Gumilar, F.; Rosenberg, A.; Targowska-Duda, K.M.; Feuerbach, D.; Jozwiak, K.; Moaddel, R.; Wainer, I.W.; Bouzat, C. Interaction of Bupropion with Muscle-Type Nicotinic Acetylcholine Receptors in Different Conformational States. Biochemistry 2009, 48, 4506-4518. [CrossRef]

115. Morales-Perez, C.L.; Noviello, C.M.; Hibbs, R.E. X-Ray Structure of the Human $\alpha 4 \beta 2$ Nicotinic Receptor. Nature 2016, 538, 411-415. [CrossRef] [PubMed]

116. Unwin, N. Refined Structure of the Nicotinic Acetylcholine Receptor at $4 \AA$ R Resolution. J. Mol. Biol. 2005, 346, 967-989. [CrossRef]

117. Arias, H.R.; Targowska-Duda, K.M.; Feuerbach, D.; Sullivan, C.J.; Maciejewski, R.; Jozwiak, K. Different Interaction between Tricyclic Antidepressants and Mecamylamine with the Human $\alpha 3 \beta 4$ Nicotinic Acetylcholine Receptor Ion Channel. Neurochem. Int. 2010, 56, 642-649. [CrossRef] [PubMed]

118. Arias, H.R.; Rosenberg, A.; Targowska-Duda, K.M.; Feuerbach, D.; Jozwiak, K.; Moaddel, R.; Wainer, I.W. Tricyclic Antidepressants and Mecamylamine Bind to Different Sites in the Human $\alpha 4 \beta 2$ Nicotinic Receptor Ion Channel. Int. J. Biochem. Cell Biol. 2010, 42, 1007-1018. [CrossRef]

119. Targowska-Duda, K.M.; Arias, H.R.; Jozwiak, K. Application of in Silico Methods to Support Experimental Data: Interactions of Antidepressants with Nicotinic Acetylcholine Receptors. Open Conf. Proc. J. 2013, 4, 11-22.

120. Harms, M.J.; Schlessman, J.L.; Chimenti, M.S.; Sue, G.R.; Damjanović, A.; García-Moreno, B. A Buried Lysine That Titrates with a Normal $p \mathrm{~K}_{\mathrm{a}}$ : Role of Conformational Flexibility at the Protein-Water Interface as a Determinant of $p \mathrm{~K}_{\mathrm{a}}$ Values. Protein Sci. Publ. Protein Soc. 2008, 17, 833-845. [CrossRef] [PubMed]

121. Harms, M.J.; Schlessman, J.L.; Sue, G.R.; García-Moreno, E.B. Arginine Residues at Internal Positions in a Protein Are Always Charged. Proc. Natl. Acad. Sci. USA 2011, 108, 18954-18959. [CrossRef] 